\title{
Intracellular pH in the Resistance Vasculature: Regulation and Functional Implications
}

\author{
Ebbe Boedtkjer Christian Aalkjaer \\ Department of Biomedicine and Water and Salt Research Center, Aarhus University, Aarhus, Denmark
}

\section{Key Words}

Endothelial cells $\cdot$ Hypertension - Hypoxia-reoxygenation • Nitric oxide - Resistance arteries · SLC4A7 • SLC9A1 • Vascular smooth muscle cells $\cdot$ Vasoconstriction $\cdot$ Vasorelaxation

\begin{abstract}
Net acid extrusion from vascular smooth muscle (VSMCs) and endothelial cells (ECs) in the wall of resistance arteries is mediated by the $\mathrm{Na}^{+}, \mathrm{HCO}_{3}^{-}$cotransporter NBCn1 (SLC4A7) and the $\mathrm{Na}^{+} / \mathrm{H}^{+}$exchanger NHE1 (SLC9A1) and is essential for intracellular $\mathrm{pH}\left(\mathrm{pH}_{\mathrm{i}}\right)$ control. Experimental evidence suggests that the $\mathrm{pH}_{\mathrm{i}}$ of VSMCs and ECs modulates both vasocontractile and vasodilatory functions in resistance arteries with implications for blood pressure regulation. The connection between disturbed $\mathrm{pH}_{\mathrm{i}}$ and altered cardiovascular function has been substantiated by a genome-wide association study showing a link between $\mathrm{NBCn} 1$ and human hypertension. On this basis, we here review the current evidence regarding (a) molecular mechanisms involved in $\mathrm{pH}_{\mathrm{i}}$ control in VSMCs and $\mathrm{ECs}$ of resistance arteries at rest and during contractions, (b) implications of disturbed $\mathrm{pH}_{\mathrm{i}}$ for resistance artery function, and (c) involvement of disturbed $\mathrm{pH}_{\mathrm{i}}$ in the pathogenesis of vascular disease. The current evidence clearly implies that $\mathrm{pH}_{\mathrm{i}}$ of VSMCs and ECs modulates vascular function and suggests that disturbed $\mathrm{pH}_{\mathrm{i}}$ either consequent to disturbed regulation or due to metabolic challenges needs to be taken into consideration as a mechanistic component of artery dysfunction and disturbed blood pressure regulation.
\end{abstract}

Copyright @ 2012 S. Karger AG, Basel

\section{Introduction}

Local or systemic deviations in $\mathrm{pH}$ may occur under both physiological and pathological conditions. For example, moderate acidification of the local environment has been described during skeletal muscle contractions [1] and high local brain activity [2], while more pronounced local acidification can be seen in malignant tumors [3] and ischemic cardiac tissue [4]. Systemic disturbances in $\mathrm{pH}$ are frequently associated with metabolic, renal, gastrointestinal and pulmonary disorders.

Changes in $\mathrm{pH}$ affect fundamental cell functions by altering the protonation state of amino acids and hence the charge distribution, conformation and function of proteins. Although most proteins show some degree of sensitivity to changes in $\mathrm{pH}$, certain proteins are much more $\mathrm{pH}$ sensitive than others. These particularly $\mathrm{pH}-$ sensitive proteins likely serve functions in sensing of $\mathrm{pH}$ disturbances and initiation of relevant physiological responses. Examples of highly $\mathrm{pH}$-sensitive proteins include ion channels (e.g. acid-sensing ion channels [5], Ltype $\mathrm{Ca}^{2+}$ channels [6] and BK channels [7]), G-proteincoupled receptors (e.g. GPR4 [8], OGR1 [8], G2A [9] and TDAG8 [10]) and enzymes (e.g. phosphofructokinase (PFK)-1 [11], NO synthase (NOS) [12,13] and endothelinconverting enzyme [14]). Although effects of $\mathrm{pH}$ on some proteins have been described in detail, the role of altered $\mathrm{pH}$ for integrated physiological functions and disease development is only slowly being understood.

\section{KARGER}

Fax +4161306 1234 E-Mail karger@karger.ch www.karger.com

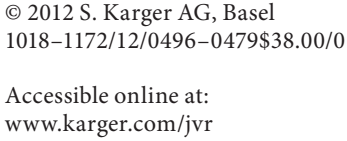

Dr. Ebbe Boedtkjer

Department of Biomedicine, Aarhus University

Ole Worms Allé 6, Building 1180

DK-8000 Aarhus C (Denmark)

Tel.+458716 7283,E-Mail eb@fi.au.dk 
It is widely accepted that extracellular $\mathrm{pH}\left(\mathrm{pH}_{\mathrm{o}}\right)$ contributes to the metabolic autoregulation of artery tone and thus participates in adjusting local blood flow to the metabolic demand $[15,16]$. In contrast, a comprehensive understanding of how intracellular $\mathrm{pH}\left(\mathrm{pH}_{\mathrm{i}}\right)$ affects vascular function has long been missing. Recently, however, we provided experimental evidence that the $\mathrm{Na}^{+}, \mathrm{HCO}_{3}^{-}$ cotransporter NBCn1 (SLC4A7), by controlling $\mathrm{pH}_{\mathrm{i}}$ and hence intracellular enzymatic activities, plays a critical role for maintaining normal function of vascular smooth muscle cells (VSMCs) and endothelial cells (ECs) [13]. In addition to altered artery function, we found that NBCn1 knockout mice have a complex disturbance of blood pressure regulation, being hypertensive at rest but protected against the blood pressure increase induced by N-nitroL-arginine methyl ester (L-NAME) intake or angiotensin II infusion [13]. The role of NBCn1 in cardiovascular control was recently substantiated by a genome-wide association study demonstrating that the single-nucleotide polymorphism (SNP) rs13082711 located close to the $\mathrm{NBCn} 1$ gene (approximately $10 \mathrm{~kb} 5^{\prime}$ of the coding region) is associated with human hypertension [17].

On this basis, it is the aim of the present review to evaluate the current evidence regarding (a) molecular mechanisms involved in $\mathrm{pH}_{\mathrm{i}}$ control in VSMCs and ECs of resistance arteries at rest and during contractions, (b) the implications of disturbed $\mathrm{pH}_{\mathrm{i}}$ in VSMCs and ECs for resistance artery function, and (c) the involvement of disturbed VSMC and $\mathrm{EC}_{\mathrm{pH}}$ in the pathogenesis of vascular disease.

\section{Mechanisms of $\mathrm{pH}_{\mathrm{i}}$ Regulation}

The overall mechanisms responsible for $\mathrm{pH}_{\mathrm{i}}$ control in VSMCs and ECs are similar to those of most other cell types and involve physicochemical buffering, metabolic acid-base production and membrane acid-base transport [18].

\section{Physicochemical Buffering}

Physicochemical buffers are conjugate acid-base pairs important for minimizing changes in $\mathrm{pH}_{\mathrm{i}}$ by accepting or donating protons following an acute acid or alkaline load, respectively.

Physicochemical buffering per se does not contribute to determining final steady-state $\mathrm{pH}_{\mathrm{i}}$ after recovery from an acid-base perturbation [19] and takes place at such speed that it is usually only apparent when one realizes that an externally induced acute change in $\mathrm{pH}_{\mathrm{i}}$ is many orders of magnitude smaller than what one would expect based on the acid-base load. One exception is the uncatalyzed hydration of $\mathrm{CO}_{2}$, which is fairly slow [18]; it has been suggested that part of the recovery seen after an abrupt intracellular alkalinization - particularly in the presence of carbonic anhydrase inhibitors - is due to this slow process followed by deprotonation of the created carbonic acid [20].

Mobile intracellular buffers may also play an important role by promoting efficient intracellular diffusion of $\mathrm{H}^{+}$equivalents [21] and thus ensure $\mathrm{pH}_{\mathrm{i}}$ uniformity, which may at least indirectly enhance membrane acidbase transport and $\mathrm{pH}_{\mathrm{i}}$ control. The mobile buffers might also enhance intercellular fluxes of $\mathrm{H}^{+}$equivalents through gap junctions [22] and hence permit dissipation of smaller local acid or alkaline loads within a larger cell volume. However, at very low $(<6.3)$ or high $(>7.6) \mathrm{pH}_{\mathrm{i}}$, gap junctions - at least in ventricular cardiomyocytes - have been shown to be almost completely closed [23] thereby protecting surrounding cells from the elevated acid or alkaline load, which could otherwise have deleterious effects.

\section{Metabolic Acid-Base Production}

Metabolic processes are an important source of intracellular acid-base equivalents particularly during pathological conditions and may cause $\mathrm{pH}_{\mathrm{i}}$ disturbances if membrane transport is not sufficiently activated to dispose of the excess acid load. Interestingly, the interaction between $\mathrm{pH}_{\mathrm{i}}$ and the intermediary metabolism is bidirectional, and even a $\mathrm{pH}_{\mathrm{i}}$ decrease of $0.2-0.3$ units is sufficient to almost completely inhibit the activity of PFK-1 [11] and consequently greatly reduce glycolytic activity [24]. The very strong $\mathrm{pH}$ dependency of PFK-1 may therefore serve as a break on glycolytic acid production under conditions of intracellular acidification.

Increased metabolic acid production has been suggested as one possible mechanism contributing to intracellular acid loading during artery contraction [25]. Other explanations, such as enhanced transport of protons over the cell membrane due to increased $\mathrm{Ca}^{2+}$ ATPase activity [26, 27], have also been put forward (see the following section and 'Effects of Artery Contraction on $\mathrm{pH}_{\mathrm{i}}$ and Regulation of Acid-Base Transport').

\section{Membrane Acid-Base Transport in VSMCs of \\ Resistance Arteries}

Intracellular $\mathrm{pH}$ of VSMCs is tightly controlled by acid-base transport across the plasma membrane. Under resting physiological conditions, net acid extrusion is mediated exclusively by $\mathrm{Na}^{+}, \mathrm{HCO}_{3}^{-}$cotransport and $\mathrm{Na}^{+} / \mathrm{H}^{+}$ exchange $[13,28,29]$, as illustrated in figure 1 . 
Fig. 1. Schematic representation of the ion transport mediated by the $\mathrm{Na}^{+}, \mathrm{HCO}_{3}^{-}$cotransporter $\mathrm{NBCn} 1$ and the $\mathrm{Na}^{+} / \mathrm{H}^{+}$exchanger NHE1. As illustrated, efficient equilibration of the carbonic buffer system means that both transporters mediate net acid extrusion. In most cell types, equilibration of the carbonic buffer system is catalyzed by intra- and extracellular carbonic anhydrases.
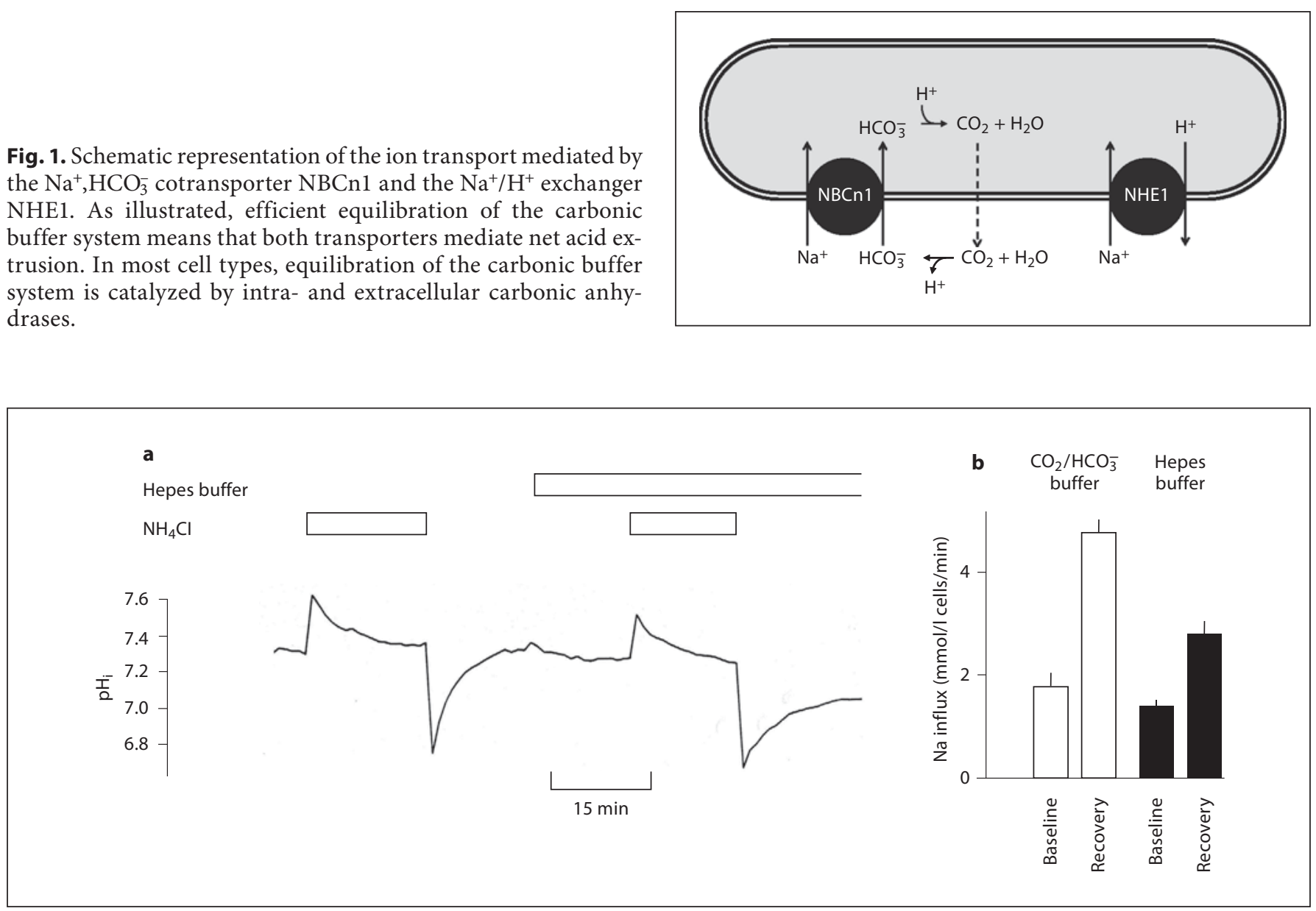

Fig. 2. $\mathrm{Na}^{+}, \mathrm{HCO}_{3}^{-}$cotransport contributes to $\mathrm{pH}_{\mathrm{i}}$ regulation in VSMCs of rat mesenteric resistance arteries. a The rate of $\mathrm{pH}_{\mathrm{i}}$ recovery from an intracellular acid load is much higher in a $\mathrm{CO}_{2} /$ $\mathrm{HCO}_{3}^{-}$-buffered solution than in a Hepes-buffered solution. Measurements were performed using the $\mathrm{pH}$-sensitive fluorophore BCECF. $\mathbf{b} \mathrm{pH}_{\mathrm{i}}$ recovery from an intracellular acid load in rat mesenteric arteries is paralleled by increased $\mathrm{Na}^{+}$influx compared to baseline. This increase in $\mathrm{Na}^{+}$influx during $\mathrm{pH}_{\mathrm{i}}$ recovery from intracellular acidification was larger in the presence than in the absence of $\mathrm{CO}_{2} / \mathrm{HCO}_{3}^{-}$. In the experiments, rat mesenteric resistance vessels were investigated in a $\mathrm{CO}_{2} / \mathrm{HCO}_{3}^{-}$or Hepes-buffered solution and the acid load was induced by incubation in $10 \mathrm{mM} \mathrm{NH}_{4} \mathrm{Cl}$ for 20 min prior to the measurement of ${ }^{22} \mathrm{Na}^{+}$influx. [This work was originally published in ref. 30; (c) The Physiological Society.]
The importance of $\mathrm{Na}^{+}, \mathrm{HCO}_{3}^{-}$cotransport for acid extrusion in VSMCs was originally suggested $[30,31]$ in isolated rat mesenteric small arteries (fig. 2) but subsequently questioned based on results from guinea pig femoral arteries [32]. Recent studies on mouse arteries confirmed the importance of $\mathrm{Na}^{+}, \mathrm{HCO}_{3}^{-}$cotransport in VSMCs of mesenteric small arteries $[13,29]$ and extended these findings to coronary and cerebral small arteries where $\mathrm{Na}^{+}, \mathrm{HCO}_{3}^{-}$cotransport also plays a prominent role [29] arguing for a general importance in the resistance vasculature. The original studies on rat isolated mesenteric arteries (fig. 2) provided the first functional characterization of an electroneutral and $\mathrm{Cl}^{-}$-independent $\mathrm{Na}^{+}, \mathrm{HCO}_{3}^{-}$ cotransport mechanism [30, 31]. Later, the electroneutral and $\mathrm{Cl}^{-}$-independent $\mathrm{Na}^{+}, \mathrm{HCO}_{3}^{-}$cotransporter $\mathrm{NBCn} 1$ was cloned from rat aorta [33], suggesting that also in conduit arteries NBCn1 may play an important role. NBCn1 expression was later demonstrated in VSMCs of mouse mesenteric, coronary and cerebral small arteries [29, 34] (fig. 3), while no expression of other known or putative $\mathrm{Na}^{+}, \mathrm{HCO}_{3}^{-}$cotransporters of the SLC4 family was detected [29]. By use of small interfering RNA (siRNA)-mediated knockdown [29] and knockout mice [13], we recently showed that $\mathrm{NBCn} 1$ is responsible for the $\mathrm{Na}^{+}, \mathrm{HCO}_{3}^{-} \mathrm{co}-$ transport activity in VSMCs of mouse mesenteric arteries during intracellular acidification (fig. 4a, b). 
a

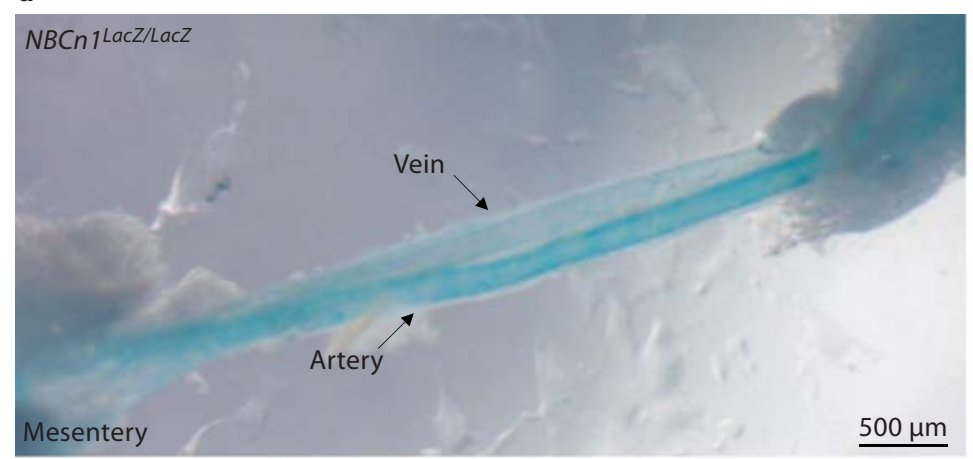

c

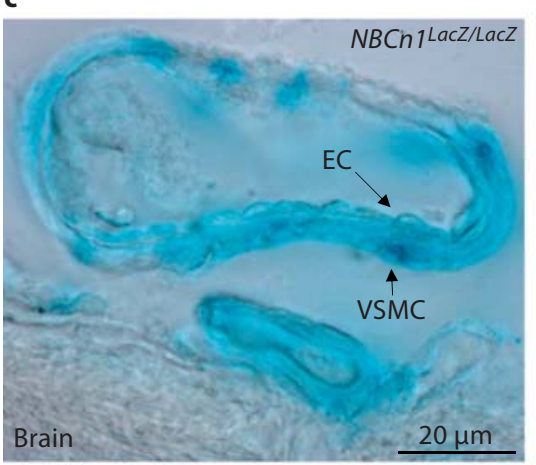

d

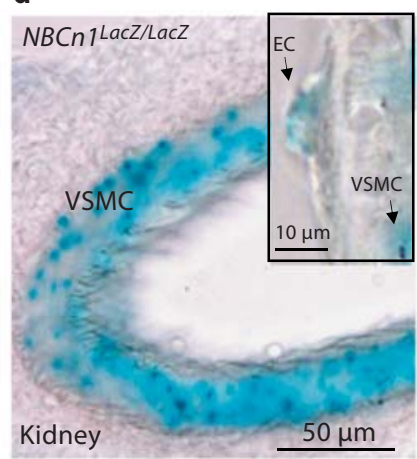

b

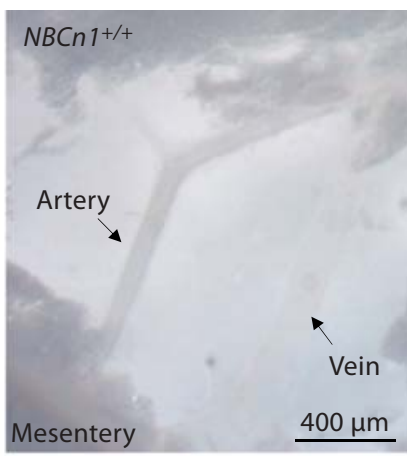

e

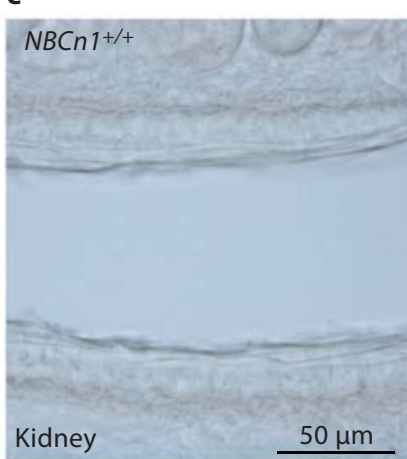

f

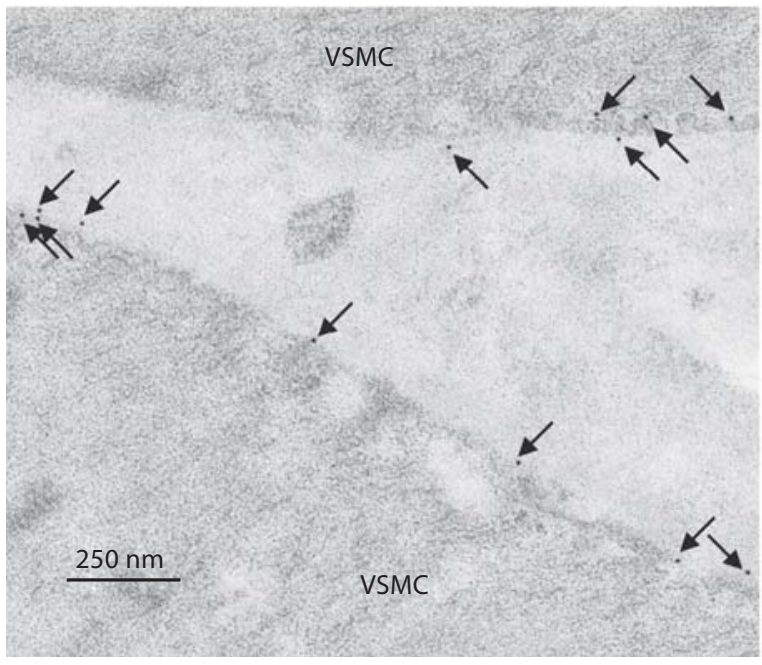

9

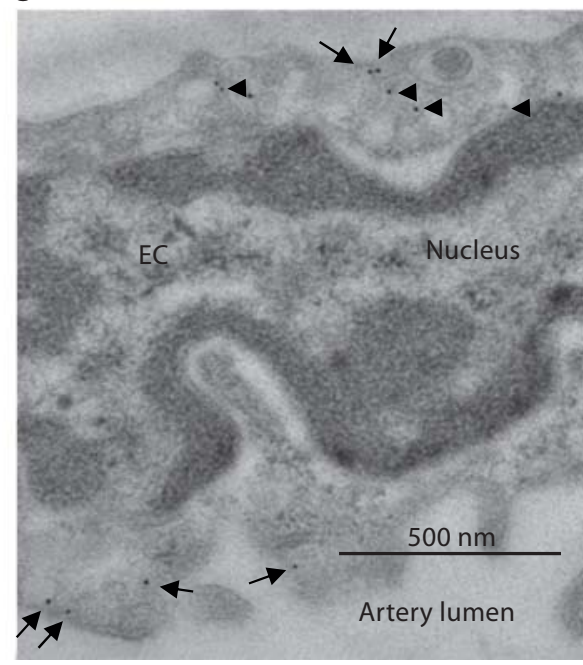

Fig. 3. $\mathrm{Na}^{+}, \mathrm{HCO}_{3}^{-}$cotransporter $\mathrm{NBCn} 1$ is strongly expressed in VSMCs and ECs of mouse resistance arteries. a-e $\beta$-Galactosidase staining of arteries and veins from gene trap mice containing a promoterless LacZ insert under transcriptional control of the NBCn1 promoter. The blue stain is a measure of NBCn1 transcriptional activity. a Whole-mount preparation of $\beta$-galactosidase-stained mesenteric arteries and veins from homozygous gene trap mice. $\mathbf{b}$ No staining was seen in mesenteric arteries and veins from wild-type mice. c Brain section ( $8 \mu \mathrm{m}$ thick) with cerebral arteries and a vein from a homozygous gene trap mouse showing staining of VSMCs and ECs. d Kidney section $(30 \mu \mathrm{m}$ thick) with an artery from a homozygous gene trap mouse showing strong staining throughout the VSMC layer (ECs not in focus).
Inset shows kidney artery with ECs in focus. e Kidney section (30 $\mu \mathrm{m}$ thick) with an artery from a wild-type mouse; no staining was observed. f Immunogold electron microscopy reveals NBCn1 expression in the plasma membrane of VSMCs in the wall of mouse mesenteric arteries. An anti- $\mathrm{NH}_{2}$-terminal $\mathrm{NBCn} 1$ antibody was employed. g Immunogold electron microscopy using an anti$\mathrm{NH}_{2}$-terminal $\mathrm{NBCn} 1$ antibody. NBCn1 expression in the plasma membrane of ECs is seen in the wall of mouse mesenteric arteries. Arrows indicate gold particles associated with the plasma membrane, and arrowheads gold particles associated with intracellular vesicles. (a-e [Originally published in ref. 34; (c) The American Physiological Society]. f, $\mathbf{g}$ [Originally published in ref. 29 and 13; (c) The American Heart Association].) 


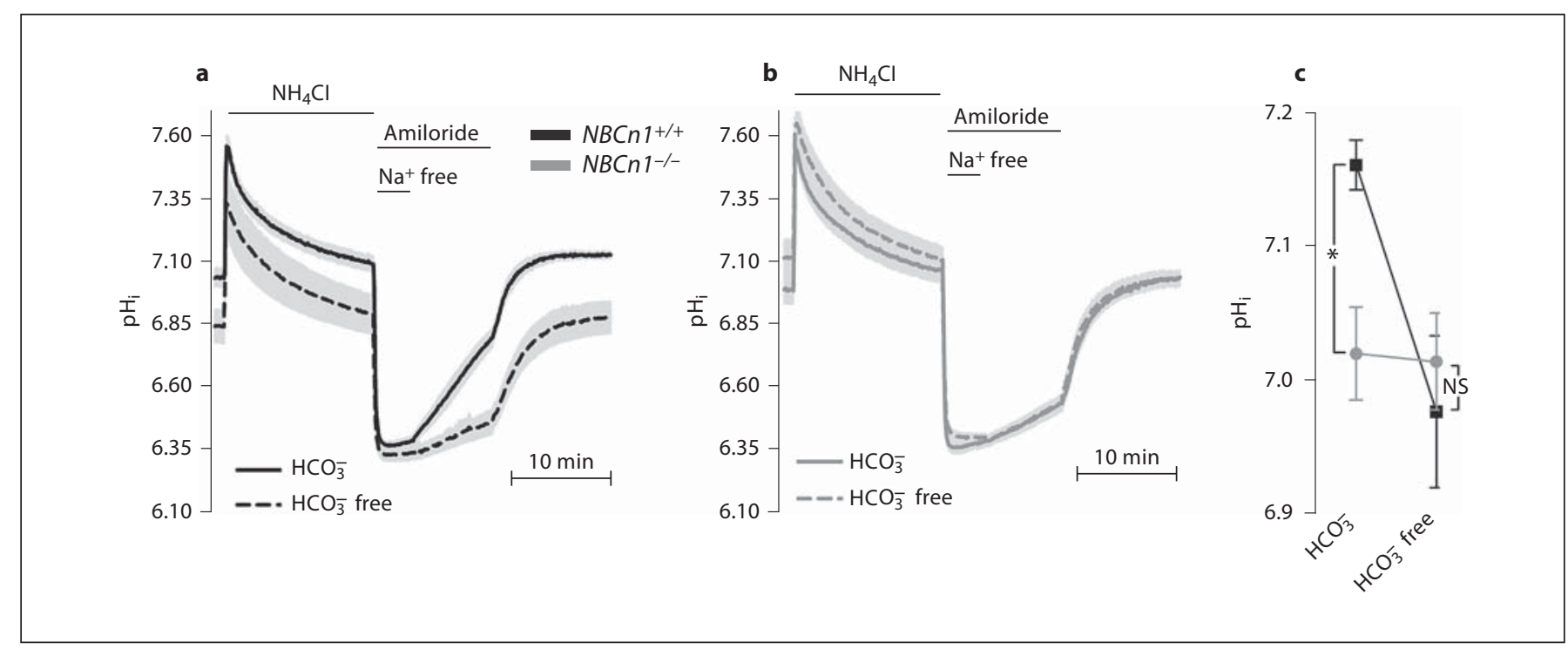

Fig. 4. $\mathrm{NBCn} 1$ mediates the $\mathrm{Na}^{+}, \mathrm{HCO}_{3}^{-}$cotransport in VSMCs of mouse resistance arteries and is crucial for steady-state $\mathrm{pH}_{\mathrm{i}}$ control. a After an $\mathrm{NH}_{4}^{+}$prepulse, VSMCs from wild-type mice $(\mathrm{n}=$ 5) displayed faster $\mathrm{pH}_{\mathrm{i}}$ recovery in the presence of $\mathrm{CO}_{2} / \mathrm{HCO}_{3}^{-}$ than in its nominal absence. b After an $\mathrm{NH}_{4}^{+}$prepulse, no difference in $\mathrm{pH}_{\mathrm{i}}$ recovery rate was seen between VSMCs from $\mathrm{NBCn} 1$ knockout mice $(\mathrm{n}=5)$ investigated with or without $\mathrm{CO}_{2} / \mathrm{HCO}_{3}^{-}$. At this low $\mathrm{pH}_{\mathrm{i}}$, the contribution of $\mathrm{CO}_{2} / \mathrm{HCO}_{3}^{-}$to intracellular buffering capacity is very small compared to the intrinsic buff- ering capacity. Hence, $\mathrm{Na}^{+}, \mathrm{HCO}_{3}^{-}$cotransport in VSMCs is abolished in NBCn1 knockout mice. c VSMCs from NBCn1 knockout mice displayed reduced steady-state $\mathrm{pH}_{\mathrm{i}}$ compared to wildtype mice $(n=6)$ in the presence but not in the absence of $\mathrm{CO}_{2} /$ $\mathrm{HCO}_{3}^{-}$. Comparisons were made by repeated measures two-way ANOVA followed by Bonferroni post hoc tests. ${ }^{*} \mathrm{p}<0.05$. NS $=$ Not significantly different vs. wild type. [This work was originally published in ref. 13; (c) The American Heart Association.]
Interestingly, while no specific pharmacological tools exist [35], $\mathrm{Na}^{+}, \mathrm{HCO}_{3}^{-}$cotransport in VSMCs is inhibited around $75 \%$ by $4,4^{\prime}$-diisothiocyanatostilbene-2, $2^{\prime}$-disulfonic acid (DIDS) [29,31]. This is in contrast to most other cell types, where $\mathrm{NBCn} 1$ is purportedly insensitive to DIDS [13, 36-38] and different from NBCn1 heterologously expressed in Xenopus oocytes, where DIDS inhibits NBCn1 activity only up to 25\% [33]. Whether the difference in DIDS sensitivity for NBCn1 expressed in different cell types is due to tissue-specific splice variation (of which multiple are known [39]), posttranslational modifications, protein-protein interactions [for an indepth discussion, see ref. 35] or other mechanisms is currently unknown.

The ubiquitously expressed $\mathrm{Na}^{+} / \mathrm{H}^{+}$exchanger NHE1 (SLC9A1) is the only known plasma membrane $\mathrm{Na}^{+} / \mathrm{H}^{+}$ exchanger isoform expressed in resistance arteries [40] and cerebrovascular tissue [41]. Using knockout mice, we have very recently shown that NHE1 is responsible for the $\mathrm{Na}^{+} / \mathrm{H}^{+}$exchange in VSMCs of isolated mesenteric resistance arteries during intracellular acidification [28] (fig. 5a). These studies were performed on 3- to 4-week- old mice since the global NHE1 knockout mice die shortly after weaning, presumably due to neurological disorders $[42,43]$. The essential role for NHE1 in $\mathrm{Na}^{+} / \mathrm{H}^{+}$exchange activity of arterial VSMCs is in agreement with its pharmacological profile being sensitive not only to amiloride but also to low concentrations $(1 \mu \mathrm{M})$ of cariporide [13].

The relative quantitative importance of $\mathrm{Na}^{+}, \mathrm{HCO}_{3}^{-}$ cotransport and $\mathrm{Na}^{+} / \mathrm{H}^{+}$exchange in VSMCs during intracellular acidification varies substantially between small arteries from mice of different genetic background (e.g. C57BL/6, FVB and NMRI), but taken as a whole, the individual contributions from $\mathrm{NBCn} 1$ and NHE1 to net acid extrusion in the $\mathrm{pH}_{\mathrm{i}}$ range from 6.5 to 6.8 appear to be of approximately similar magnitude $[13,28,29,40]$, which is also the case in rat mesenteric small arteries [31]. In the near-physiological $\mathrm{pH}_{\mathrm{i}}$ range, however, $\mathrm{NBCn} 1$ is the dominating mediator of net acid extrusion from resting VSMCs based on the findings that knockout [13] or siRNA-mediated knockdown [29] of NBCn1 or omission of $\mathrm{CO}_{2} / \mathrm{HCO}_{3}^{-}[13,28,29]$ reduce $\mathrm{VSMC} \mathrm{pH}_{\mathrm{i}}$ up to 0.4 units (fig. 4c). In contrast, knockout of NHE1 only affects 


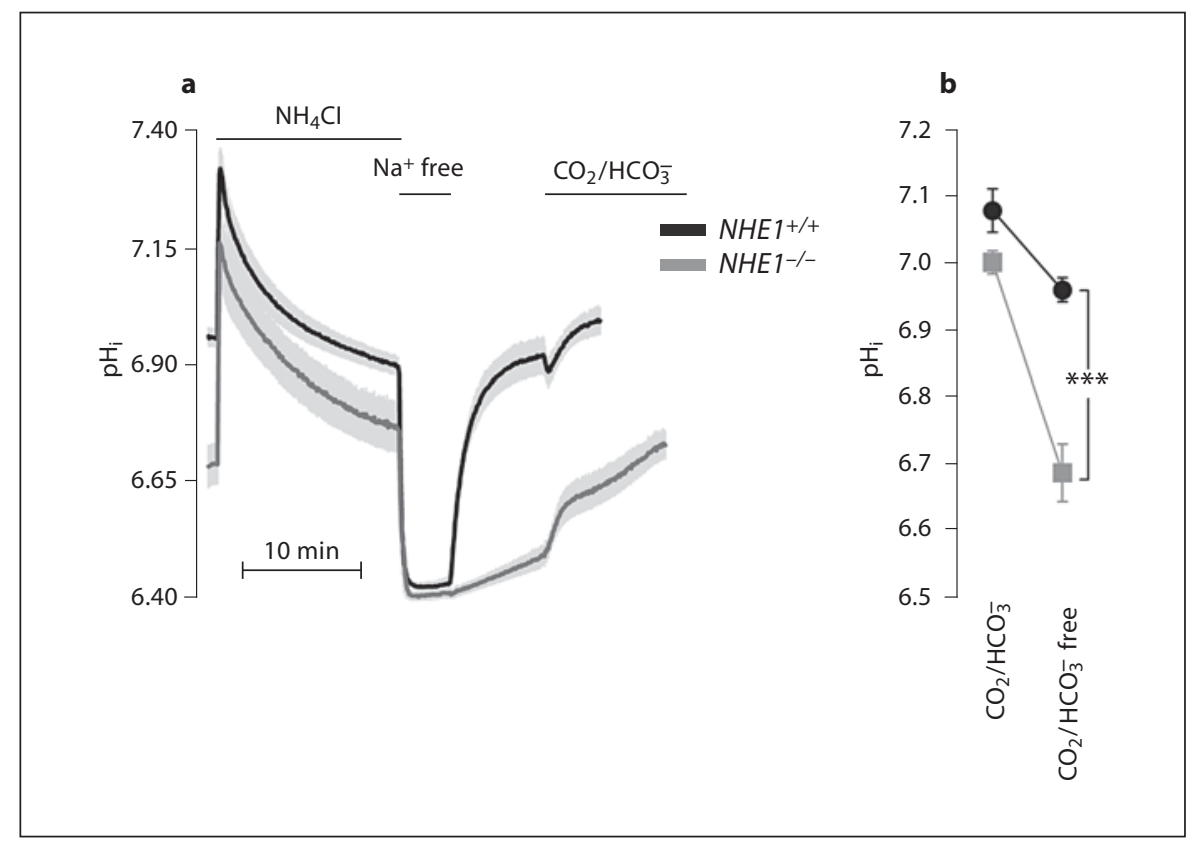

Fig. 5. $\mathrm{NHE} 1$ mediates the $\mathrm{Na}^{+} / \mathrm{H}^{+}$exchange in VSMCs of mouse resistance arteries. NHE1 is important for steady-state $\mathrm{pH}_{\mathrm{i}}$ control only in the absence of $\mathrm{CO}_{2} / \mathrm{HCO}_{3}^{-}$. a In the absence of $\mathrm{CO}_{2} /$ $\mathrm{HCO}_{3}^{-}$, the $\mathrm{Na}^{+}$-dependent $\mathrm{pH}_{\mathrm{i}}$ recovery was abolished in VSMCs of arteries from NHE1 knockout mice $(n=5-7)$. Experiments were performed in the absence of $\mathrm{CO}_{2} / \mathrm{HCO}_{3}^{-}$except for the final part (as indicated). b In the absence of $\mathrm{CO}_{2} / \mathrm{HCO}_{3}^{-}$, steady-state
$\mathrm{pH}_{\mathrm{i}}$ was lower in VSMCs of arteries from NHE1 knockout than wild-type mice. In the presence of $\mathrm{CO}_{2} / \mathrm{HCO}_{3}^{-}$, no significant difference in steady-state $\mathrm{pH}_{\mathrm{i}}$ was seen between VSMCs of arteries from NHE1 knockout and wild-type mice $(n=5-8)$. Comparisons were made with a two-way ANOVA followed by Bonferroni post hoc tests. ${ }^{* *} \mathrm{p}<0.001$ vs. wild type. [This work was originally published in ref. 28; (C) Physiological Society.] steady-state $\mathrm{pH}_{\mathrm{i}}$ of VSMCs when investigated in the nominal absence of $\mathrm{CO}_{2} / \mathrm{HCO}_{3}^{-}$[28] (fig. 5b). Hence, although NBCn1 and NHE1 perform ostensibly similar transport functions (i.e. net extrusion of $1 \mathrm{H}^{+}$equivalent in exchange for $1 \mathrm{Na}^{+}$; fig. 1), our findings demonstrate that NBCn1 plays a major role in the control of steady-state $\mathrm{pH}_{\mathrm{i}}[13,29]$ while NHE1 appears to be a major acid extruder at low $\mathrm{pH}_{\mathrm{i}}$ but functionally inactive at normal resting $\mathrm{pH}_{\mathrm{i}}$ levels [28].

Base extrusion from VSMCs has not been studied to the same extent as acid extrusion. In resistance arteries, there is clear functional evidence for $\mathrm{Cl}^{-} / \mathrm{HCO}_{3}^{-}$exchange [31], which appears to play an important role for $\mathrm{pH}_{\mathrm{i}}$ recovery from intracellular alkalinization. Based on RNA and protein analyses, AE2 (SLC4A2) and AE3 (SLC4A3) are expressed in arteries [44], but the precise role of individual $\mathrm{Cl}^{-} / \mathrm{HCO}_{3}^{-}$exchangers for $\mathrm{VSMC} \mathrm{pH}_{\mathrm{i}}$ regulation and artery function remains to be established. Notably, $\mathrm{Cl}^{-} / \mathrm{HCO}_{3}^{-}$exchange in VSMCs in addition to a role in $\mathrm{pH}_{\mathrm{i}}$ regulation also contributes to maintaining a high intracellular $\mathrm{Cl}^{-}$concentration [45] and hence to the electro- chemical gradient favoring $\mathrm{Cl}^{-}$efflux and membrane depolarization upon opening of $\mathrm{Cl}^{-}$channels in resting VSMCs [46].

In addition to the dedicated acid-base transporters highlighted above, it should be kept in mind that other membrane transport proteins present in VSMCs also move acid-base equivalents across the plasma membrane. As an example, the transport process mediated by the $\mathrm{Ca}^{2+}$-ATPase includes antiport of $\mathrm{H}^{+}$[47], which by acting as counter-ions reduce the electrogenicity and hence the energy requirement of the transport process, but at the same time may contribute to intra- and extracellular $\mathrm{pH}$ changes. As described in 'Effects of Artery Contraction on $\mathrm{pH}_{\mathrm{i}}$ and Regulation of Acid-Base Transport', $\mathrm{H}^{+}$transport by the plasma membrane $\mathrm{Ca}^{2+}$ ATPase has been suggested as a primary mechanism for contractioninduced intracellular acidification of smooth muscle cells [26]. It is also possible that acid-base equivalents such as $\mathrm{H}^{+}$or $\mathrm{HCO}_{3}^{-}$may permeate ion channels $[48,49]$, although this has not yet been sufficiently investigated for VSMCs. 
It should finally be noted that although the discussion above focuses on ion transport across the plasma membrane, high transport activities for acid-base equivalents are also present in membranes of intracellular organelles, particularly those of lysosomes and mitochondria [50]. In addition to serving important functions for these specialized organelles (e.g. acid-induced activation of intraorganellar enzymes), the accumulation of acid in organelles also removes acid from the cytosol and thereby potentially contributes to control or disturbances of cytosolic $\mathrm{pH}$.

\section{Membrane Acid-Base Transport in ECs of Resistance} Arteries

The role of membrane acid-base transport for $\mathrm{pH}_{\mathrm{i}}$ control in ECs has been much less studied than in VSMCs. Until recently, our understanding of $\mathrm{EC} \mathrm{pH}_{\mathrm{i}}$ regulation relied entirely on measurements in cultured cells, but we have now studied the mechanisms of $\mathrm{pH}_{\mathrm{i}}$ control in ECs of small isolated arteries using fluorescence confocal microscopy [40]. In our opinion, this is important not only to avoid phenotypic changes during cell culture (see the following section) but also to investigate the relevance of $\mathrm{EC} \mathrm{pH}_{\mathrm{i}}$ for integrated artery responses such as endothelium-dependent vasorelaxation (see 'Effects of $\mathrm{pH}_{\mathrm{i}}$ on Small Artery Function'), which cannot be studied meaningfully in cultured cells.

Previous molecular expression data from artery homogenates suggested that NBCn1 and NHE1 are the only relevant $\mathrm{Na}^{+}$-dependent members of the SLC4 and SLC9 families expressed in resistance arteries $[29,40]$. Evidence for NBCn1 expression in ECs of small arteries has also been provided [13, 34, 51] (fig. 3); recently, we showed functionally that $\mathrm{NBCn} 1$ and NHE1 are responsible for the $\mathrm{Na}^{+}$-dependent acid extrusion from ECs $[13,28]$. In congruence with our findings in VSMCs, we found that while both NBCn1 and NHE1 contribute to acid extrusion during intracellular acidification, only $\mathrm{NBCn} 1$ appears to be active in the near-physiological $\mathrm{pH}_{\mathrm{i}}$ range and consequently important for steady-state $\mathrm{pH}_{\mathrm{i}}$ control in ECs under resting physiological conditions $[13,28]$. In contrast to VSMCs, the transport by $\mathrm{NBCn} 1$ in ECs was unaffected by $200 \mu \mathrm{M}$ DIDS [13]. The reason for this difference in pharmacological sensitivity between $\mathrm{NBCn} 1$ expressed in these closely appositioned cell types is currently unknown. For a more elaborate discussion of the effects of DIDS, see Boedtkjer et al. [35]. As expected, and similar to VSMCs, the $\mathrm{Na}^{+} / \mathrm{H}^{+}$exchange in ECs was inhibited by amiloride or low concentrations $(1 \mu \mathrm{M})$ of the NHE1-selective inhibitor cariporide [40].

Intracellular $\mathrm{pH}$ in the Resistance Vasculature
Membrane Acid-Base Transport in Other Blood Vessels and Cultured Vascular Cells

The transport characteristics described above are based on experiments with mesenteric, coronary and cerebral small arteries with an internal diameter between 150 and $250 \mu \mathrm{m}$ [29]. Similarly sized arteries have been shown to contribute significantly to vascular resistance [52] and hence to the regulation of local blood flow and control of systemic blood pressure. It is likely, however, that the findings regarding molecular mechanisms of $\mathrm{pH}_{\mathrm{i}}$ control are also applicable to other arterial beds and differently sized arteries. Hence, we have found that NBCn1 is responsible for the $\mathrm{Na}^{+}, \mathrm{HCO}_{3}^{-}$cotransport in conduit arteries [unpubl. observation], and NBCn1 expression has been detected in renal arteries [34] (fig. 3d), heart capillaries [51] and also in veins [34] (fig. 3a, c). Despite this, we cannot of course completely exclude that other transport mechanisms than $\mathrm{Na}^{+}, \mathrm{HCO}_{3}^{-}$cotransport and $\mathrm{Na}^{+}$/ $\mathrm{H}^{+}$exchange or different $\mathrm{NBC}$ or NHE isoforms may play a role in blood vessels of different size or origin or under different physiological or pathological conditions.

It is well known that cells in culture differ from native cells in a number of ways. It is not surprising therefore that although $\mathrm{Na}^{+}$-dependent $\mathrm{HCO}_{3}^{-}$transport has been described in cultured VSMC- and EC-like cells [53-56], the characteristics of this transport differ somewhat from the transport observed in isolated arteries (see the two preceding sections) and has for instance been suggested to be at least partly coupled to net $\mathrm{Cl}^{-}$transport [54-56]. These differences in transport characteristics between cultured cells and freshly isolated tissue preparations are most easily explained by a change in protein expression pattern during the culture process. This explanation seems further supported by the finding that in contrast to isolated arteries, cultured ECs from brain microvessels [57] and cultured rat aortic smooth muscle cells (A7r5 [unpubl. observation]) express transcripts for a large number of different $\mathrm{Na}^{+}$-dependent $\mathrm{HCO}_{3}^{-}$transporters.

Another important example of culture-induced changes relating to artery function is the shift from a contractile to a synthetic VSMC phenotype [58]. The loss of contractile function seen during culture obviously renders cultured VSMCs less representative of native arterial VSMCs and unsuited for studies regarding vasomotor characteristics. Since many of the culture-induced changes also take place in response to vascular injury and are prominent in atherosclerotic and restenotic lesions [59], studies on cultured VSMCs may, however, provide important insights into mechanisms involved in the de-

J Vasc Res 2012;49:479-496 
velopment and progression of these prevalent vascular conditions. Considering the importance of acid-base transport for altering fundamental cell functions (e.g. cell proliferation and migration) implicated in changes of artery morphology $[28,60,61]$ (see also 'Hypertension'), it may moreover be very relevant to study $\mathrm{pH}_{\mathrm{i}}$-regulatory pathways in VSMCs from arteries with atherosclerotic or restenotic lesions.

\section{Effects of $\mathrm{pH}_{\mathrm{o}}$ on $\mathrm{pH}_{\mathrm{i}}$}

In the vascular wall, changes in $\mathrm{pH}_{\mathrm{o}}$ are followed by changes in $\mathrm{pH}_{\mathrm{i}}$ in the same direction, and a new steadystate $\mathrm{pH}_{\mathrm{i}}$ is typically reached within a couple of minutes $[62,63]$. Although reports vary, there is general consensus that the change in steady-state $\mathrm{pH}_{\mathrm{i}}$ is between 50 and $75 \%$ of the imposed change in $\mathrm{pH}_{\mathrm{o}}$ [63-65]. The magnitude of change in $\mathrm{pH}_{\mathrm{i}}$ depends, however, on whether the extracellular acid-base disturbance is respiratory (i.e. hyperor hypocapnic) or metabolic (i.e. normocapnic) in nature, with $\mathrm{pH}_{\mathrm{i}}$ being more sensitive to respiratory than metabolic disturbances $[62,64]$.

The change in $\mathrm{pH}_{\mathrm{i}}$ following a change in $\mathrm{pH}_{\mathrm{o}}$ purportedly results from altered movement of acid-base equivalents across the plasma membrane. This may be explained by changes in fluxes of small ionic species such as $\mathrm{H}^{+}$, $\mathrm{OH}^{-}$or $\mathrm{HCO}_{3}^{-}$through ion channels, a mechanism supported for instance by the finding that several $\mathrm{Cl}^{-}$channels are also permeable to $\mathrm{HCO}_{3}^{-}[48,49]$ (see also 'Membrane Acid-Base Transport in VSMCs of Resistance Arteries'). In addition, uncharged forms of acid-base pairs or related species (e.g. monocarboxylic acids, $\mathrm{CO}_{2}$ or $\mathrm{NH}_{3}$; see also 'Effects of $\mathrm{pH}_{\mathrm{i}}$ on Small Artery Function') move rapidly across cell membranes by passive diffusion through the lipid bilayer or through gas channels [66$71]$, whereas charged species such as metabolic monocarboxylates can move via specific transporters expressed in the VSMC plasma membrane [72]. Furthermore, it is well established that the $\mathrm{Na}^{+} / \mathrm{H}^{+}$exchangers are inhibited by extracellular acidosis [73, 74], which will further contribute to the intracellular buildup of protons. $\mathrm{Na}^{+}, \mathrm{HCO}_{3}^{-} \mathrm{Co}-$ transport also appears to be inhibited by acidic extracellular conditions, but whereas maximal inhibition of $\mathrm{Na}^{+} /$ $\mathrm{H}^{+}$exchange has been reported around $\mathrm{pH}_{\mathrm{o}} 6.8$, maximal inhibition of $\mathrm{Na}^{+}, \mathrm{HCO}_{3}^{-}$cotransport requires $\mathrm{pH}_{\mathrm{o}}$ levels below 6.3 [75]. Further investigations are needed to clarify the relative contributions from each of these mechanisms in the vascular wall and determine their functional impact in ECs and VSMCs.

\section{Effects of $\mathrm{pH}_{\mathrm{i}}$ on Small Artery Function}

A large number of studies have investigated the response of arteries to acute intracellular acid-base disturbances induced by addition and subsequent washout of weak acids or bases such as $\mathrm{NH}_{4}^{+}$, acetate, lactate, pyruvate or butyrate [66-69], which in aqueous solution coexist with their conjugate acid or base. These maneuvers typically cause $\mathrm{pH}_{\mathrm{i}}$ changes of large magnitude (often around 0.5 units) and take place within a few tens of seconds [29]. The $\mathrm{pH}_{\mathrm{i}}$ changes observed are explained by the relative permeability of the plasma membrane to the acid and its conjugate base. During a so-called $\mathrm{NH}_{4}^{+}$prepulse [18], the $\mathrm{pH}_{\mathrm{i}}$ responses are: (a) an abrupt intracellular alkalinization upon extracellular addition of $\mathrm{NH}_{4} \mathrm{Cl}$ due to fast influx of $\mathrm{NH}_{3}$ through the lipid bilayer and potentially via gas channels, (b) a gradual recovery of $\mathrm{pH}_{\mathrm{i}}$ due to slower influx of $\mathrm{NH}_{4}^{+}$through $\mathrm{K}^{+}$conductances and base extrusion by the anion exchangers, and (c) an abrupt intracellular acidification upon washout of extracellular $\mathrm{NH}_{4} \mathrm{Cl}$ as $\mathrm{NH}_{3}$ quickly leaves the cells and $\mathrm{H}^{+}$is liberated from intracellular $\mathrm{NH}_{4}^{+}$. The vast majority of studies from resistance arteries report that acute intracellular acidification induced by an $\mathrm{NH}_{4}^{+}$prepulse or by an acute hypercapnic challenge causes vasoconstriction [30, 76-79] due to an increase in intracellular $\left[\mathrm{Ca}^{2+}\right]$ in the VSMCs $[80$, 81]. There are only few examples of studies suggesting vasodilatation in response to acute intracellular acidification [63]. The mechanisms linking acute changes in VSMC $\mathrm{pH}_{\mathrm{i}}$ to changes in $\left[\mathrm{Ca}^{2+}\right]_{\mathrm{i}}$ are not completely clear, but effects on membrane potential [7, 81, 82], transport of $\mathrm{Ca}^{2+}$ across the plasmalemma or the sarcoplasmic reticulum membrane $[79,83-85]$ and competition between $\mathrm{H}^{+}$ and cytosolic $\mathrm{Ca}^{2+}$ for buffer binding $[80,86]$ have all been suggested.

Studies investigating how sustained changes in $\mathrm{pH}_{\mathrm{i}}$ modify contractile responses of small arteries have previously been limited by the difficulty of experimentally inducing prolonged intracellular acidification without changing extracellular conditions. Using knockout mice for acid-base transporters, we have, however, recently been able to circumvent these difficulties $[13,28]$. The effects of sustained changes in $\mathrm{pH}_{\mathrm{i}}$ on arterial tone regulation appear more subtle than those induced for instance by washout of $\mathrm{NH}_{4} \mathrm{Cl}$; but as detailed below (both following sections), this may in part be due to opposing effects of low $\mathrm{pH}_{\mathrm{i}}$ in the VSMCs and ECs $[13,28]$, i.e. low VSMC $\mathrm{pH}_{\mathrm{i}}$ tends to reduce VSMC contractility while low $\mathrm{EC}_{\mathrm{pH}}$ tends to reduce NO-mediated vasodilation and hence increase contractility. The effects of sustained changes in 


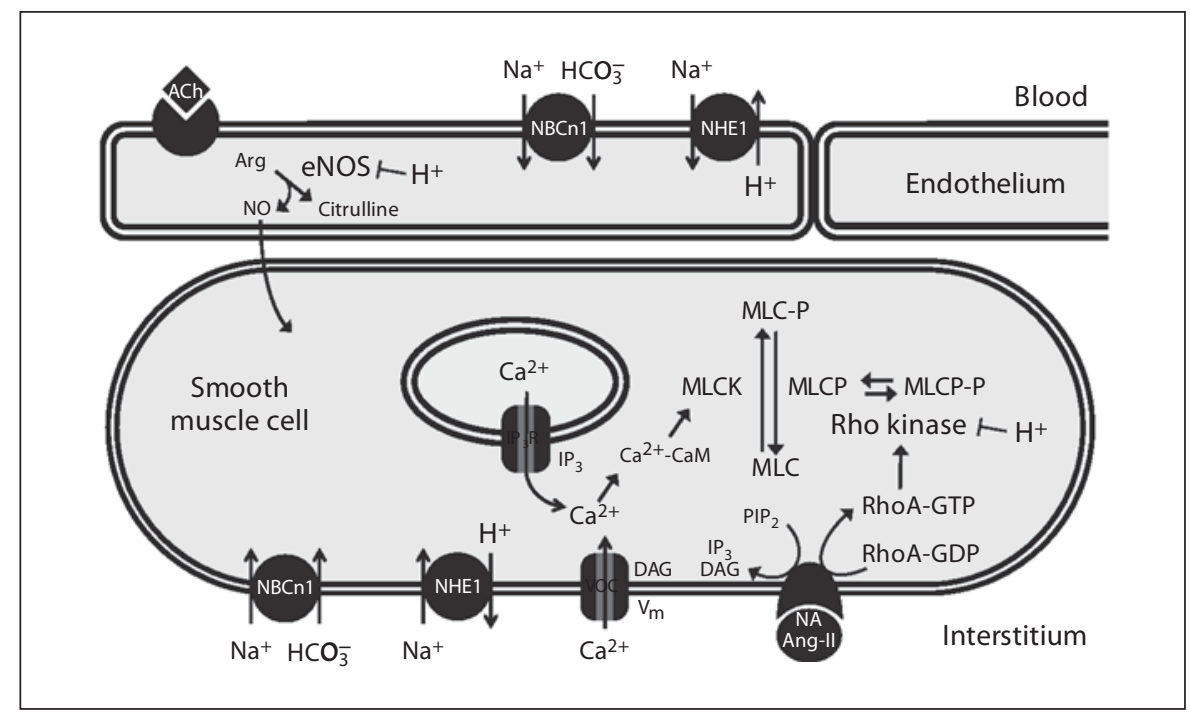

Fig. 6. Diagrammatic representation of the pathways affected by sustained changes in $\mathrm{pH}_{\mathrm{i}}$ in the arterial wall. As illustrated in figure $1, \mathrm{NBCn} 1$ contributes to $\mathrm{pH}_{\mathrm{i}}$ control by transporting $\mathrm{HCO}_{3}^{-}$, which in turn consumes cytosolic $\mathrm{H}^{+}$. ACh = Acetylcholine; Ang-II = angiotensin II; CaM = calmodulin; DAG = diacyl glycerol; eNOS = endothelial NOS; $\mathrm{IP}_{3}=$ inositol 1,4,5-trisphosphate; MLC-P = phosphorylated MLC; MLCK = MLC kinase; MLCP = MLC phosphatase; MLCP-P = phosphorylated (inactive) MLC phosphatase; $\mathrm{NA}=$ noradrenaline; $\mathrm{PIP}_{2}=$ phosphati-

$\mathrm{pH}_{\mathrm{i}}$ on vascular function are summarized in figure 6 and addressed in further detail below.

\section{Effects of Sustained Intracellular Acidification on \\ VSMC Function}

As mentioned above, acute changes in $\mathrm{pH}_{\mathrm{i}}$ have prominent effects on the intracellular $\mathrm{Ca}^{2+}$ concentration in VSMCs $[80,81]$. In contrast, $\mathrm{Ca}^{2+}$ handling in VSMCs does not appear to be affected during prolonged intracellular acidification $[13,29]$. Interestingly, changes in $\mathrm{pH}_{\mathrm{i}}$ have been suggested to influence VSMC Ca ${ }^{2+}$ sensitivity $[13,28,29,87,88]$, although early studies employing chemical permeabilization were in conflict as to whether the $\mathrm{Ca}^{2+}$ sensitivity was increased or reduced at low $\mathrm{pH}_{\mathrm{i}}[87$, 88]. Using knockout mice for NBCn1 and NHE1, we recently investigated the effects of sustained intracellular acidification on VSMC function under physiological extracellular conditions $[13,28]$. After pharmacological inhibition of endothelium-dependent vasorelaxation in arteries from both mouse models, we found that intracellular acidification reduced VSMC $\mathrm{Ca}^{2+}$ sensitivity and showed moreover that this effect was abolished following rho kinase inhibition $[13,28]$. The influence of pharmaco- dylinositol-4,5-bisphosphate; $\mathrm{V}_{\mathrm{m}}=$ membrane potential. The plasma membrane ion channel illustrates $\mathrm{Ca}^{2+}$ entry through receptor-activated cation channels and voltage-sensitive $\mathrm{Ca}^{2+}$ channels. The ion channel in the sarcoplasmic reticulum represents $\mathrm{Ca}^{2+}$ release through $\mathrm{IP}_{3}$ receptors. As illustrated, there is evidence for a direct inhibitory effect of low $\mathrm{pH}$ on rho kinase activity [13], but the inhibition of rho-kinase-mediated signaling by $\mathrm{pH}_{\mathrm{i}}$ may also in part be secondary to effects further upstream in the signaling cascade. logical rho kinase inhibition (using e.g. Y-27632 or fasudil) on resistance artery function is dramatic and complete inhibition in mesenteric small arteries reduces noradrenaline-sensitivity $\left(-\log \mathrm{EC}_{50}\right)$ by a half $\log$ unit and maximal active tension development by approximately 50\% [13]. The isolated rho kinase in vitro has a smaller intrinsic $\mathrm{pH}$ sensitivity [13] than some of the most $\mathrm{pH}$-sensitive enzymes described to date (e.g. the NOS [12] and PFK1 [11]). However, since no more than $10 \%$ pharmacological inhibition of the rho kinase is required to significantly reduce noradrenaline sensitivity with respect to tension development [13], even a moderate intrinsic $\mathrm{pH}$ sensitivity is likely to have important biological consequences. Notably, we have shown that pharmacological and $\mathrm{pH}_{\mathrm{i}}$-mediated rho kinase inhibition of similar magnitude produces approximately equivalent changes in artery contractions [13] suggesting that the intrinsic $\mathrm{pH}$ sensitivity of the rho kinase plays a significant role for $\mathrm{pH}_{\mathrm{i}}$-mediated effects on artery function. Reduced rho kinase activity at low $\mathrm{pH}_{\mathrm{i}}$ was further confirmed by our finding that phosphorylation of the myosin light chain (MLC) phosphatase targeting subunit (MYPT) at $\mathrm{Thr}^{850}$ was reduced in arteries from NBCn1knockout mice [13]. Consistent with effects of $\mathrm{pH}_{\mathrm{i}}$ on rho- 


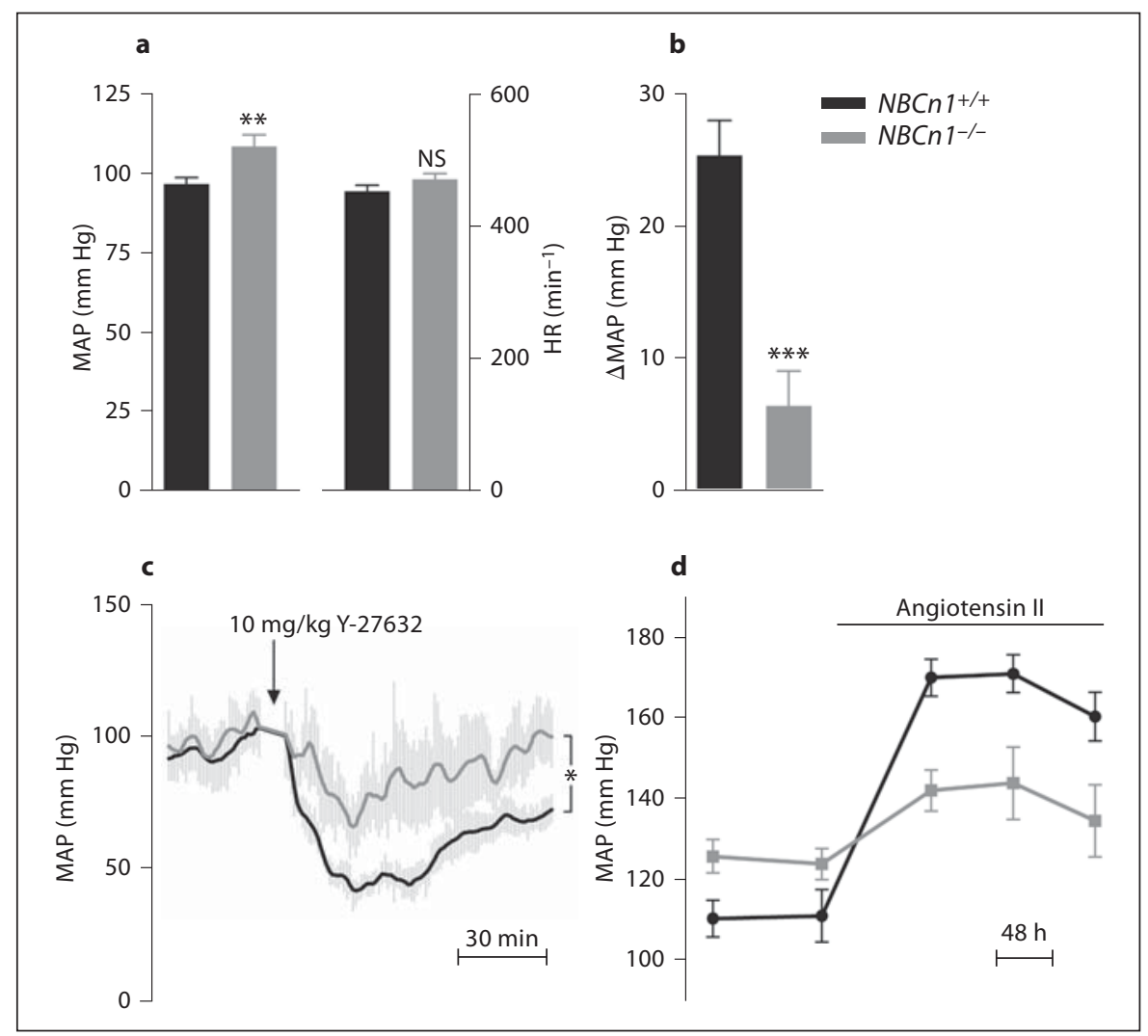

Fig. 7. Blood pressure effects of disturbed $\mathrm{pH}_{\mathrm{i}}$ regulation. $\mathrm{NBCn} 1$ knockout mice are mildly hypertensive at rest, display attenuated blood pressure responses to NOS and rho kinase inhibition and are resistant to developing hypertension to angiotensin II. a Resting mean arterial blood pressure (MAP) was higher in NBCn1 knockout mice compared to wild-type mice while resting heart rate (HR) was not significantly different. The measurements were performed by radiotelemetry $(n=12-14)$ and similar results were obtained by tail cuff measurements (not shown). b The increase in mean arterial blood pressure ( $\triangle \mathrm{MAP})$ upon treatment with LNAME in the drinking water was attenuated in NBCn1 knockout mice compared to wild-type mice $(n=12-14)$. L-NAME intake relative to body weight was not different between NBCn1 knock- out and wild-type mice (not shown). c The change in mean arterial blood pressure ( $\triangle \mathrm{MAP})$ following injection of Y-27632 (10 $\mathrm{mg} / \mathrm{kg}$ body weight i.p.) was smaller in NBCn1 knockout compared to wild-type mice. The star denotes significant interaction (i.e. the effect of Y-27632 was significantly different between NBCn1 knockout and wild-type mice; comparison was made with repeated-measure two-way ANOVA). d Mean arterial blood pressure before and during continuous angiotensin II infusion by an osmotic minipump in NBCn1 knockout and wild-type mice $(\mathrm{n}=7-8)$. The increase in mean arterial blood pressure during angiotensin II infusion was reduced in NBCn1 knockout compared to wild-type mice. [This work was originally published in ref. 13; (c) The American Heart Association.] kinase-dependent signaling in vivo, the blood pressure responses to pharmacological inhibition with Y-27632 or stimulation with angiotensin II were attenuated in NBCn1 knockout compared to wild-type mice [13] (fig. 7c, d; see also 'Hypertension').

In principle, effects of $\mathrm{pH}_{\mathrm{i}}$ on VSMC Ca ${ }^{2+}$ sensitivity could be due not only to signaling cascades modulating MLC phosphatase activity but also secondary to effects on the MLC kinase. This, however, seems unlikely because (a) the difference in VSMC $\mathrm{Ca}^{2+}$ sensitivity in that case would not be expected to be sensitive to rho kinase inhibition, (b) experimental evidence suggests that the
MLC kinase displays almost constant catalytic activity in the broad $\mathrm{pH}$ spectrum between 6.5 and 9.0 [89], and (c) binding of $\mathrm{Ca}^{2+}$ to calmodulin and the interaction of the $\mathrm{Ca}^{2+}$-calmodulin complex with its target proteins including the MLCK are either unaffected or even slightly enhanced at low $\mathrm{pH}[90,91]$.

In studies based on genetically modified animals, it is imperative to consider whether the observed phenotypic changes are directly caused by the altered expression of the protein in question or secondary for instance to compensatory up- or downregulation of other proteins. The causative role of $\mathrm{pH}_{\mathrm{i}}$ in our experiments was strongly sup- 
ported by the comparable effects of NBCn1 and NHE1 knockout observed under conditions of intracellular acidification $[13,28]$. The similar effects of low $\mathrm{pH}_{\mathrm{i}}$ observed in arteries from NBCn1 and NHE1 knockout mice under in vitro conditions furthermore suggest that acute rather than chronic (e.g. developmental) effects of $\mathrm{pH}_{\mathrm{i}}$ are responsible for the phenotype since intracellular acidification under in vivo circumstances (i.e. in the presence of $\left.\mathrm{CO}_{2} / \mathrm{HCO}_{3}^{-}\right)$is expected in the NBCn1 but not in the NHE1 knockout mice $[13,28]$ (fig. 4c, 5b; see also 'Membrane Acid-Base Transport in VSMCs of Resistance Arteries' and 'Membrane Acid-Base Transport in ECs of Resistance Arteries'). In addition, the causative role and acute effect of $\mathrm{pH}_{\mathrm{i}}$ was supported by the finding that the lower VSMC $\mathrm{Ca}^{2+}$ sensitivity in arteries from $\mathrm{NBCn} 1$ knockout mice was evident only in the presence of $\mathrm{CO}_{2} /$ $\mathrm{HCO}_{3}^{-}$when $\mathrm{pH}_{\mathrm{i}}$ is reduced [13]. In the absence of $\mathrm{CO}_{2} /$ $\mathrm{HCO}_{3}^{-}$, no difference in $\mathrm{pH}_{\mathrm{i}}$ was present and no difference in $\mathrm{Ca}^{2+}$ sensitivity was observed [13]. Conversely, effects of NHE1 knockout on both $\mathrm{pH}_{\mathrm{i}}$ and $\mathrm{Ca}^{2+}$ sensitivity were seen only in the absence of $\mathrm{CO}_{2} / \mathrm{HCO}_{3}^{-}[28]$.

\section{Effects of Sustained Intracellular Acidification on EC Function}

The vascular endothelium of resistance arteries is responsible for initiating a large number of signaling cascades modulating active tension development in the surrounding VSMCs. Both vasocontractile (e.g. endothelin and thromboxane) and vasodilatory factors or pathways (e.g. NO, prostacyclin and endothelium-derived hyperpolarizing factor) can be released or initiated from the endothelium [92]. In most cases, however, activation of the endothelium with agonists such as acetylcholine or bradykinin or mechanical stimulation by increased shear stress initiate a predominantly vasodilatory response $[13,93]$.

In light of the high secretory activity of the vascular endothelium and the potential of $\mathrm{pH}$ to alter enzymatic activity, it is not surprising that changes in $\mathrm{pH}_{\mathrm{i}}$ modify $\mathrm{EC}$ function. Using knockout mice for $\mathrm{NBCn} 1$ and NHE1, we have shown that the vasodilatory response to acetylcholine stimulation is greatly attenuated at low $\mathrm{pH}_{\mathrm{i}}[13,28]$. Under $\mathrm{CO}_{2} / \mathrm{HCO}_{3}^{-}$-buffered conditions where the ECs in arteries from $\mathrm{NBCn} 1$ knockout mice are acidified around $0.25 \mathrm{pH}$ units compared to arteries from wild-type mice, endothelium-dependent vasorelaxation was approximately $30 \%$ reduced [13]. This difference in vasodilatory response between arteries from $\mathrm{NBCn} 1$ knockout and wild-type mice was completely abolished after L-NAME preincubation suggesting an effect on NO-dependent signaling [13]. In principle, reduced NO-mediated signaling may arise due to inhibited NO synthesis, enhanced NO degradation or reduced effect of NO on the VSMCs. The response to the exogenous NO donor S-nitroso-N-acetylpenicillamine was similar in arteries from NBCn1 knockout and wild-type mice and preincubation with the superoxide scavengers tempol or polyethylene glycol superoxide dismutase did not rescue the vasodilatory response of arteries from $\mathrm{NBCn} 1$ knockout mice suggesting an effect on NO synthesis [13]. In agreement, intraluminal concentrations of NO (measured with NO-sensitive electrodes) during acetylcholine stimulation were reduced in mesenteric arteries from NBCn1 knockout compared to wildtype mice, and NOS activity (measured as L-NAME-sensitive arginine to citrulline conversion) in intact aortic segments was attenuated [13]. In support of $\mathrm{pH}_{\mathrm{i}}$ being the causative link between NBCn1 knockout and reduced endothelium-dependent vasorelaxation, there was no difference in vasodilatory function between arteries from $\mathrm{NBCn} 1$ knockout and wild-type mice when investigated in the absence of $\mathrm{CO}_{2} / \mathrm{HCO}_{3}^{-}$where $\mathrm{pH}_{\mathrm{i}}$ is similar in the two groups [13]. Further substantiating this observation, we recently showed that $\mathrm{EC} \mathrm{pH}_{\mathrm{i}}$ in arteries from NHE1 knockout mice was reduced around 0.5 units when investigated in the absence of $\mathrm{CO}_{2} / \mathrm{HCO}_{3}^{-}$and under these conditions L-NAME-sensitive vasodilatory responses to acetylcholine were almost completely abolished [28]. In contrast, in the presence of $\mathrm{CO}_{2} / \mathrm{HCO}_{3}^{-}$, both $\mathrm{EC}_{\mathrm{pH}}$ and the vasodilatory response to acetylcholine were very similar between arteries from NHE1 knockout and wild-type mice [28]. In arteries from both NBCn1 and NHE1 knockout mice, endothelial $\mathrm{Ca}^{2+}$ handling appeared unaffected by low $\mathrm{pH}_{\mathrm{i}}[13,28]$. In congruence with our findings in isolated arteries, earlier studies have shown that the isolated NOS when investigated in vitro has a bell-shaped $\mathrm{pH}$ dependency with maximum activity around $\mathrm{pH} 7.5$ and substantially reduced activities at both lower and higher $\mathrm{pH}$ values even within the physiological $\mathrm{pH}_{\mathrm{i}}$ range [12] Supporting the conclusion that NO production is inhibited at low $\mathrm{pH}_{\mathrm{i}}$ due to the intrinsic $\mathrm{pH}$ sensitivity of the endothelial NOS, we found no difference in the level of total or Ser ${ }^{1177}$ phosphorylated NOS expression between arteries from NBCn1 knockout and wild-type mice [13].

The effects of NBCn1 knockout on NO-mediated responses in isolated resistance arteries were paralleled by an increased resting blood pressure (fig. 7a) and an almost completely abolished blood pressure increase to LNAME treatment in NBCn1 knockout compared to wildtype mice [13] (fig. 7b; see also 'Hypertension') suggesting that the $\mathrm{pH}_{\mathrm{i}}$-mediated inhibition of NOS activity is also important in vivo. 


\section{Effects of Artery Contraction on $\mathrm{pH}_{\mathrm{i}}$ and Regulation of Acid-Base Transport}

Several studies have investigated the effect of vasoconstriction on VSMC $\mathrm{pH}_{\mathrm{i}}$. When investigated in the presence of $\mathrm{CO}_{2} / \mathrm{HCO}_{3}^{-}$, acute contractions induced by noradrenaline [29], angiotensin II [27], $\mathrm{Ca}^{2+}$ ionophores [27, 29 ] or membrane depolarization with elevated extracellular concentrations of $\mathrm{K}^{+}$[25] have been reported to cause intracellular acidification within the first few minutes. The reason for this acidification has not been conclusively determined, but the acidification has been shown to be secondary to the rise in intracellular $\mathrm{Ca}^{2+}$ concentration, since it is inhibited by intracellular loading with the $\mathrm{Ca}^{2+}$ chelator BAPTA [27]. Intracellular acid loading via membrane transport has been suggested as a mechanism for the contraction-induced intracellular acidification: the $\mathrm{Ca}^{2+}$-ATPase transports $\mathrm{Ca}^{2+}$ across cell membranes in exchange for $\mathrm{H}^{+}$, and since it does so at a higher rate during contractions, it may contribute to the intracellular acidification $[26,27]$. Supporting this notion, extracellular alkalinization has been reported during contraction-induced intracellular acidifications [26]. The initial acidification described above has in several studies been reported to be followed by a slower recovery of $\mathrm{pH}_{\mathrm{i}}$ [29], which is dependent on $\mathrm{CO}_{2} / \mathrm{HCO}_{3}^{-}$ $[25,29]$ and inhibited by DIDS [25]. The acidification has furthermore been shown to be augmented in the absence of extracellular $\mathrm{Na}^{+}$[25]. Taken together, these findings strongly suggest that $\mathrm{Na}^{+}, \mathrm{HCO}_{3}^{-}$cotransport in VSMCs is activated during contractions of rat mesenteric arteries and plays an important role for $\mathrm{pH}_{\mathrm{i}}$ control under these conditions. Activation of $\mathrm{Na}^{+}$-dependent $\mathrm{HCO}_{3}^{-}$transport by agonist stimulation has also been reported in other cell types [94, 95], but the intracellular signaling mechanisms still need to be investigated.

\section{Involvement of $\mathrm{pH}_{\mathrm{i}}$ Disturbances in Vascular Disease}

As outlined in 'Effects of $\mathrm{pH}_{\mathrm{i}}$ on Small Artery Function', changes in $\mathrm{EC}$ and $\mathrm{VSMC} \mathrm{pH}_{\mathrm{i}}$ alter both vasodilatory and vasocontractile functions. It is therefore conceivable that dysregulation of $\mathrm{pH}_{\mathrm{i}}$ in ECs or VSMCs contributes to disease development in conditions involving vascular dysfunction. In addition, particularly NHE1 may have cellular effects, which act not only via changes in $\mathrm{pH}$ but may also rely on interactions with extracellular matrix components, the cytoskeleton or intracellular signaling pathways $[96,97]$. The $\mathrm{pH}_{\mathrm{i}}$-independent effects have been shown to be important for cell migration and proliferation $[96,97]$ and hence may be of consequence for arterial structure development [28].

The hypothesis that acid-base transport and $\mathrm{pH}_{\mathrm{i}}$ contribute to disease development or associated complications has fostered a number of studies proposing among others that $\mathrm{pH}_{\mathrm{i}}$ disturbances are associated with vascular manifestations of hypertension and development of endothelial dysfunction following hypoxia-reoxygenation events. The current evidence for involvement of NBCn1 or NHE1 in these conditions is discussed below.

\section{Hypertension}

Considering the effects of VSMC and $\mathrm{EC}_{\mathrm{pH}}$ on both vasocontractile and vasodilatory functions of resistance arteries and hence potentially on peripheral vascular resistance, it is obvious to ask whether $\mathrm{pH}_{\mathrm{i}}$ and altered function of membrane acid-base transporters contribute to blood pressure disturbances. This question was recently addressed by a genome-wide association study showing that the SNP rs13082711 close to the NBCn1 gene (approximately $10 \mathrm{~kb} 5^{\prime}$ of the coding region) is associated with hypertension in humans [17]. Although the effect size was rather small (around $0.3 \mathrm{~mm} \mathrm{Hg}$ ), the finding is consistent with $\mathrm{NBCn} 1$ being of major importance for vascular function and having therapeutic potential in the treatment of vascular disease. It is important to recognize that the effect size of a given SNP does not necessarily correlate well with the therapeutic potential of that target. For instance, SNPs located in the gene for HMG-CoA (3-hydroxy-3-methyl-glutaryl-coenzyme A) reductase have small effect sizes explaining only a $5 \%$ difference in LDL cholesterol $[98,99]$; yet, inhibition of the HMG-CoA reductase with statins reduces LDL cholesterol levels substantially (30-40\% [100]) and are used extensively to protect against cardiovascular events. This difference between genetic and pharmacological effects is likely explained by SNPs altering the activity or expression of a given target only slightly while pharmacological intervention may allow for an almost complete inhibition [98]. At present, it is unclear whether the rs13082711 SNP alters NBCn1 expression or is in disequilibrium with SNPs inside the $\mathrm{NBCn} 1$ coding region, which may confer a change in transport activity. Experiments to address potential effects of the rs13082711 SNP on NBCn1 function and expression would provide important information regarding the role of $\mathrm{NBCn} 1$ and $\mathrm{pH}_{\mathrm{i}}$ for human cardiovascular function in vivo.

The animal studies described above ('Effects of Sustained Intracellular Acidification on VSMC Function' 
and 'Effects of Sustained Intracellular Acidification on EC Function') imply that NBCn1 plays a considerable role in vivo: global NBCn1 knockout mice have a complicated blood pressure disturbance being mildly hypertensive at rest but protected against the blood pressure increase induced by NOS inhibition (with L-NAME) or angiontensin II infusion [13] (fig. 7). Apparently, the balance between activities in the NO- and rho-kinase-dependent signaling cascades under a given condition determines whether the NBCn1 knockout mice have higher or lower blood pressure relative to the wild-type mice. The current evidence strongly implies that NBCn1 has potential for modulating artery function and blood pressure regulation in mice. Although genetic evidence suggests that similar mechanisms are at play in humans, further verification is required to determine the potential pathophysiological role and therapeutic potential of NBCn1 in human vascular disease and blood pressure dysregulation.

Studies have shown that $\mathrm{Na}^{+} / \mathrm{H}^{+}$exchange activity is increased in erythrocytes and platelets from up to $50 \%$ of humans with primary hypertension [101], whereas linkage analyses and sequencing data have provided no evidence for mutations in NHE1 associated with hypertension [102104]. Increased $\mathrm{Na}^{+} / \mathrm{H}^{+}$exchange activity has also been described in arteries from spontaneously hypertensive rats (SHR) compared to Wistar-Kyoto (WKY) control rats [105-107] resulting in an increased VSMC steady-state $\mathrm{pH}_{\mathrm{i}}$ and a faster recovery from intracellular acidification in the absence of $\mathrm{CO}_{2} / \mathrm{HCO}_{3}{ }^{-}$[106]. The majority of data suggests no difference in total NHE1 protein or mRNA level between VSMCs from SHR and WKY rats [108-112], although at least one study employing cultured VSMCs has reported higher NHE1 abundance in SHR compared to WKY [113]. No mutations within the coding region of NHE1 have been found in SHR [107] and the mechanistic background for the increased $\mathrm{Na}^{+} / \mathrm{H}^{+}$exchange activity therefore remains undetermined, although effects on trafficking, protein stability, posttranslational modifications [35] or the activity of signaling cascades modulating NHE1 activity [35] could be involved. In line with the above description that NHE1 is an important acid extruder at low $\mathrm{pH}_{\mathrm{i}}$ but functionally inactive in the near-physiological range $[13,28]$ (see also 'Membrane Acid-Base Transport in VSMCs of Resistance Arteries' and 'Membrane Acid-Base Transport in ECs of Resistance Arteries'), no difference in steady-state $\mathrm{pH}_{\mathrm{i}}$ or recovery rate after an intracellular acid load was seen between arteries from adult SHR and WKY rats in the presence of $\mathrm{CO}_{2} / \mathrm{HCO}_{3}{ }^{-}[105,106]$. Interestingly, evidence has been provided for a more alkaline $\mathrm{pH}_{\mathrm{i}}$ in arteries from young (5-week-old) SHR compared to WKY rats [105]. In vivo, one would not expect any difference in bulk VSMC $\mathrm{pH}_{\mathrm{i}}$ between adult SHR and WKY rats and it seems unlikely that acute effects of $\mathrm{pH}_{\mathrm{i}}$ are directly responsible for the hypertensive phenotype observed. Nonetheless, NHE1 per se could be important since it has been shown to have transport-independent effects on phenomena such as cell migration and proliferation $[96,97]$. It should also be noted that the alkaline $\mathrm{pH}_{\mathrm{i}}$ measured in the young SHR coincides temporally with the development of hypertension and inward arterial remodeling [105], which may provide a long-term structural effect even after the $\mathrm{pH}_{\mathrm{i}}$ difference disappears. Although differences in bulk VSMC $\mathrm{pH}_{\mathrm{i}}$ are not expected under physiological conditions, it is also possible that $\mathrm{pH}$ differences in subcellular domains or restricted extracellular compartments are present and play a role.

Transgenic mouse models have also provided insights relevant to the question of NHE1 in hypertension. Mice overexpressing NHE1 have salt-sensitive hypertension [114], while NHE1 knockout mice are hypotensive and display altered artery structure [28]. In line with a role of NHE1 for cell proliferation and migration, our recent findings suggest that NHE1 is important for normal development of artery morphology in the systemic circulation since arteries from NHE1 knockout mice have a reduced media to lumen ratio [28]. It should be noted, however, that NHE1 knockout mice are hypotensive [28] and whether the thinning of the arterial walls is a consequence of or contributes to the low blood pressure requires further investigation.

While the discussion above has focused on the role of $\mathrm{pH}_{\mathrm{i}}$ and membrane acid-base transport in arteries from the systemic circulation, recent evidence suggests that intracellular acid-base homeostasis also plays a very significant role in the pulmonary circulation. Knockout mice for NHE1 have been shown to be unsusceptible to developing pulmonary hypertension and pulmonary artery remodeling [60]. In accordance with a role for NHE1 in pulmonary artery remodeling, siRNA-mediated knockdown of NHE1 was subsequently shown to inhibit proliferation, migration and hypertrophy of VSMC-derived cells [61].

\section{Hypoxia-Reoxygenation}

Reduced blood perfusion typically results in acid-base disturbances, and a number of studies have suggested that acid-base transport plays a role for the outcome of ischemic disease. As such, hypoxia-reoxygenation causes myocardial damage, which can be reduced by prior inhibition of $\mathrm{Na}^{+} / \mathrm{H}^{+}$exchange [115-117]. Similarly, endothe- 
lial dysfunction can be caused by hypoxia-reoxygenation [118-120] and beneficial effects of specific $\mathrm{Na}^{+} / \mathrm{H}^{+}$exchange inhibitors have been suggested $[120,121]$. While these findings support that $\mathrm{Na}^{+} / \mathrm{H}^{+}$exchange is involved in the pathogenesis of ischemic cell injury, the relative contribution of $\mathrm{Na}^{+} / \mathrm{H}^{+}$exchange inhibition in cardiomyocytes, ECs and potentially other cell types to alleviate development of myocardial dysfunction still requires further investigation. Mechanistically, the $\mathrm{Na}^{+}$-loading capacity of the $\mathrm{Na}^{+} / \mathrm{H}^{+}$exchangers may, by affecting $\mathrm{Na}^{+} /$ $\mathrm{Ca}^{2+}$ exchange activity, result in intracellular $\mathrm{Ca}^{2+}$ overload and consequent cell injury. The results are, however, not unambiguous and inhibitors of $\mathrm{Na}^{+} / \mathrm{H}^{+}$exchange have been suggested to defend cardiomyocytes against reoxygenation damage owing to a reduced $\mathrm{Ca}^{2+}$ overload [122] or independently of $\mathrm{Ca}^{2+}$ overload [123].

We recently showed that $\mathrm{H}_{2} \mathrm{O}_{2}$ inhibits $\mathrm{Na}^{+} / \mathrm{H}^{+}$exchange in arterial ECs in situ [40] and considering the increased amounts of reactive oxygen species present during ischemia-reperfusion events [124], we suggested that $\mathrm{H}_{2} \mathrm{O}_{2}$-mediated NHE1 inhibition might act as a cellular defense mechanism to reduce cellular $\mathrm{Na}^{+}$uptake, intracellular $\mathrm{Ca}^{2+}$ overload and cell damage [40]. Interestingly, we furthermore showed that insulin - which has been shown to protect against ischemia-reperfusion injury [125] - stimulates intracellular $\mathrm{H}_{2} \mathrm{O}_{2}$ accumulation in the vascular wall and inhibits $\mathrm{Na}^{+} / \mathrm{H}^{+}$exchange activity [40]. The effects of insulin were prominent in ECs but evident in VSMCs primarily at supraphysiological concentrations [40]. This could indicate that the ECs are the source of the $\mathrm{H}_{2} \mathrm{O}_{2}$ production which would be consistent with the lack of an inhibitory effect of insulin on $\mathrm{Na}^{+} / \mathrm{H}^{+}$ exchange activity in primary monocultures of canine VSMCs [126], although the apparent difference could also be explained by much lower concentrations of insulin used in the cell culture experiments.

To exploit the potential beneficial effects of NHE1 inhibition on the outcome of ischemic heart disease, clinical trials using the $\mathrm{Na}^{+} / \mathrm{H}^{+}$exchange inhibitors cariporide or eniporide to treat cardiac disease have been performed $[127,128]$, but even though positive treatment effects were seen in some patient subgroups, the development of neurological side effects has precluded wider clinical use.

Considering the ostensibly similar transport functions of NHE1 and NBCn1 [35], it seems likely that $\mathrm{NBCn} 1$ is also involved in the development of cellular dysfunction after hypoxia-reoxygenation. In fact, in the arterial wall, $\mathrm{Na}^{+}, \mathrm{HCO}_{3}^{-}$cotransport could be expected to contribute more to cellular $\mathrm{Na}^{+}$uptake than NHE1 since (a) at resting $\mathrm{pH}_{\mathrm{i}}$ values, $\mathrm{NBCn} 1$ is more active than
NHE1 while both transporters are activated by intracellular acidification $[13,28,29]$, (b) compared to NHE1 activity, which is strongly inhibited by extracellular acidification, $\mathrm{Na}^{+}, \mathrm{HCO}_{3}^{-}$cotransport activity is much less affected [75], and (c) during hypoxia-reoxygenation events, local concentrations of reactive oxygen species rise [124], which inhibits NHE1 activity but has no effect on NBCn1 activity [40]. Although the contribution of $\mathrm{Na}^{+}, \mathrm{HCO}_{3}^{-}$ cotransport to myocardial damage following ischemiareperfusion has not yet been conclusively determined, in one study it has at least been shown that combined inhibition of $\mathrm{Na}^{+} / \mathrm{H}^{+}$exchange (using cariporide) and $\mathrm{Na}^{+}, \mathrm{HCO}_{3}^{-}$cotransport (using DIDS) is necessary to protect against the development of reoxygenation-induced hypercontracture while either inhibitor alone is insufficient [129]. Unfortunately, no pharmacological $\mathrm{Na}^{+}, \mathrm{HCO}_{3}^{-}$ cotransport inhibitor with sufficient specificity for in vivo administration has been described up to now [35] limiting both experimental investigations of potential benefits of $\mathrm{Na}^{+}, \mathrm{HCO}_{3}^{-}$cotransport inhibition and eventual clinical applications.

\section{Conclusion and Perspectives}

Increasing experimental evidence suggests that $\mathrm{pH}_{\mathrm{i}}$ of VSMCs and ECs modulate vascular function. Acute intracellular acidification has been consistently shown to cause VSMC contraction due to an increase in intracellular $\left[\mathrm{Ca}^{2+}\right.$. Longer-term $\mathrm{pH}_{\mathrm{i}}$ regulation is governed by the $\mathrm{Na}^{+}, \mathrm{HCO}_{3}^{-}$cotransporter $\mathrm{NBCn} 1$ and the $\mathrm{Na}^{+} / \mathrm{H}^{+}$exchanger NHE1, which are responsible for net cellular acid extrusion (fig. 1) and play significant roles for maintaining normal artery structure and function. During sustained intracellular acidification, vasocontractile as well as vasodilatory functions are inhibited. The link between sustained disturbances in $\mathrm{pH}_{\mathrm{i}}$ and the development of vascular dysfunction involves $\mathrm{pH}_{\mathrm{i}}$-mediated changes in intracellular enzymatic activity with consequences for NO-mediated and rho-kinase-dependent signaling (fig. 6). Most cell functions depend upon efficient catalysis of key biochemical reactions, and it is consequently likely that many other aspects of cell function than vasomotor function are also affected by disturbed $\mathrm{pH}_{\mathrm{i}}$ in the vascular wall and in other organ systems. Additional studies are required to determine the full potential of $\mathrm{pH}_{\mathrm{i}}$ in adjusting cell function under different physiological and pathophysiological conditions.

Initial attempts have been made to target acid-base transporters in the treatment of cardiovascular disease. 
Inhibitors of NHE1 were, however, unsuccessful because of severe neurological side effects. Consequently, other targets or selective pharmacological tools are needed to inhibit acid-base transporters in a tissue-specific manner. Recent studies have shown that polymorphisms close to the gene for $\mathrm{NBCn} 1$ are associated with human hypertension, and $\mathrm{NBCn} 1$ consequently represents an attractive novel target which should be investigated for positive treatment effects in major cardiovascular conditions including hypertension and ischemic heart disease.

\section{Acknowledgment}

Related work in the authors' laboratories is supported by the Danish Council for Independent Research (10-094816 to E.B. and 271-06-0472 to C.A.), the Lundbeck Foundation (R93-A8859 to E.B.) and the Danish Heart Foundation (08-10-R68-A2179B719-22494 to E.B.).

\section{References}

-1 Steinhagen C, Hirche HJ, Nestle HW, Bovenkamp U, Hosselmann I: The interstitial pH of the working gastrocnemius muscle of the dog. Pflugers Arch 1976;367:151-156.

$\checkmark 2$ Xiong ZQ, Stringer JL: Extracellular pH responses in CA1 and the dentate gyrus during electrical stimulation, seizure discharges, and spreading depression. J Neurophysiol 2000;83:3519-3524.

$\checkmark 3$ Cardone RA, Casavola V, Reshkin SJ: The role of disturbed $\mathrm{pH}$ dynamics and the $\mathrm{Na}^{+}$/ $\mathrm{H}^{+}$exchanger in metastasis. Nat Rev Cancer 2005;5:786-795.

4 Yan GX, Kleber AG: Changes in extracellular and intracellular $\mathrm{pH}$ in ischemic rabbit papillary muscle. Circ Res 1992;71:460-470.

5 Waldmann R, Champigny G, Bassilana F, Heurteaux C, Lazdunski M: A proton-gated cation channel involved in acid-sensing. Nature 1997;386:173-177.

6 Irisawa H, Sato R: Intra- and extracellular actions of proton on the calcium current of isolated guinea pig ventricular cells. Circ Res 1986;59:348-355.

7 Schubert R, Krien U, Gagov H: Protons inhibit the $\mathrm{BK}_{\mathrm{Ca}}$ channel of rat small artery smooth muscle cells. J Vasc Res 2001;38:3038.

8 Ludwig MG, Vanek M, Guerini D, Gasser JA, Jones CE, Junker U, Hofstetter H, Wolf RM, Seuwen K: Proton-sensing G-protein-coupled receptors. Nature 2003;425:93-98.

9 Murakami N, Yokomizo T, Okuno T, Shimizu T: G2A is a proton-sensing G-proteincoupled receptor antagonized by lysophosphatidylcholine. J Biol Chem 2004;279: 42484-42491.

-10 Wang JQ, Kon J, Mogi C, Tobo M, Damirin A, Sato K, Komachi M, Malchinkhuu E, Murata N, Kimura T, Kuwabara A, Wakamatsu K, Koizumi H, Uede T, Tsujimoto G, Kurose H, Sato T, Harada A, Misawa N, Tomura H, Okajima F: TDAG8 is a proton-sensing and psychosine-sensitive G-protein-coupled receptor. J Biol Chem 2004;279:45626-45633.

-11 Trivedi B, Danforth WH: Effect of $\mathrm{pH}$ on the kinetics of frog muscle phosphofructokinase. J Biol Chem 1966;241:4110-4112.
12 Fleming I, Hecker M, Busse R: Intracellular alkalinization induced by bradykinin sustains activation of the constitutive nitric oxide synthase in endothelial cells. Circ Res 1994;74:1220-1226.

13 Boedtkjer E, Praetorius J, Matchkov VV, Stankevicius E, Mogensen S, Füchtbauer AC, Simonsen U, Fuchtbauer EM, Aalkjaer C: Disruption of $\mathrm{Na}^{+}, \mathrm{HCO}_{3}^{-}$-cotransporter NBCn1 (slc4a7) inhibits NO-mediated vasorelaxation, smooth muscle $\mathrm{Ca}^{2+}$-sensitivity and hypertension development in mice. Circulation 2011;124:1819-1829.

14 Ahn K, Beningo K, Olds G, Hupe D: The endothelin-converting enzyme from human umbilical vein is a membrane-bound metalloprotease similar to that from bovine aortic endothelial cells. Proc Natl Acad Sci USA 1992;89:8606-8610

15 Vavilala MS, Lee LA, Lam AM: Cerebral blood flow and vascular physiology. Anesthesiol Clin North America 2002;20:247264.

16 Gaskell WH: On the tonicity of the heart and blood vessels. J Physiol 1880;3:48-92.

17 Ehret GB, Munroe PB, Rice KM, Bochud M, Johnson AD, Chasman DI, Smith AV, Tobin MD, Verwoert GC, Hwang SJ, Pihur V, Vollenweider P, O’Reilly PF, Amin N, BraggGresham JL, Teumer A, Glazer NL, Launer L, Zhao JH, Aulchenko Y, Heath S, Sober S, Parsa A, Luan J, Arora P, Dehghan A, Zhang F, Lucas G, Hicks AA, Jackson AU, Peden JF, Tanaka T, Wild SH, Rudan I, Igl W, Milaneschi Y, Parker AN, Fava C, Chambers JC, Fox ER, Kumari M, Go MJ, van der Harst P, Kao WH, Sjogren M, Vinay DG, Alexander M, Tabara Y, Shaw-Hawkins S, Whincup PH, Liu Y, Shi G, Kuusisto J, Tayo B, Seielstad M, Sim X, Nguyen KD, Lehtimaki T, Matullo G, Wu Y, Gaunt TR, Onland-Moret NC, Cooper MN, Platou CG, Org E, Hardy R, Dahgam S, Palmen J, Vitart V, Braund PS, Kuznetsova T, Uiterwaal CS, Adeyemo A, Palmas W, Campbell H, Ludwig B, Tomaszewski M, Tzoulaki I, Palmer ND, Aspelund T, Garcia M, Chang YP, O'Connell JR, Steinle NI, Grobbee DE, Arking DE, Kardia SL, Morri- son AC, Hernandez D, Najjar S, McArdle WL, Hadley D, Brown MJ, Connell JM, Hingorani AD, Day IN, Lawlor DA, Beilby JP, Lawrence RW, Clarke R, Hopewell JC, Ongen $\mathrm{H}$, Dreisbach AW, Li Y, Young JH, Bis JC, Kahonen M, Viikari J, Adair LS, Lee NR, Chen MH, Olden M, Pattaro C, Bolton JA, Kottgen A, Bergmann S, Mooser V, Chaturvedi N, Frayling TM, Islam M, Jafar TH, Erdmann J, Kulkarni SR, Bornstein SR, Grassler J, Groop L, Voight BF, Kettunen J, Howard P, Taylor A, Guarrera S, Ricceri F, Emilsson V, Plump A, Barroso I, Khaw KT, Weder AB, Hunt SC, Sun YV, Bergman RN, Collins FS, Bonnycastle LL, Scott LJ, Stringham HM, Peltonen L, Perola M, Vartiainen E, Brand SM, Staessen JA, Wang TJ, Burton PR, Artigas MS, Dong Y, Snieder H, Wang X, Zhu H, Lohman KK, Rudock ME, Heckbert SR, Smith NL, Wiggins KL, Doumatey A, Shriner D, Veldre G, Viigimaa M, Kinra S, Prabhakaran D, Tripathy V, Langefeld CD, Rosengren A, Thelle DS, Corsi AM, Singleton A, Forrester T, Hilton G, McKenzie CA, Salako T, Iwai N, Kita Y, Ogihara T, Ohkubo T, Okamura T, Ueshima H, Umemura S, Eyheramendy S, Meitinger T, Wichmann HE, Cho YS, Kim HL, Lee JY, Scott J, Sehmi JS, Zhang W, Hedblad B, Nilsson P, Smith GD, Wong A, Narisu N, Stancakova A, Raffel LJ, Yao J, Kathiresan S, O’Donnell CJ, Schwartz SM, Ikram MA, Longstreth WT Jr, Mosley TH, Seshadri S, Shrine NR, Wain LV, Morken MA, Swift AJ, Laitinen J, Prokopenko I, Zitting P, Cooper JA, Humphries SE, Danesh J, Rasheed A, Goel A, Hamsten A, Watkins H, Bakker SJ, van Gilst WH, Janipalli CS, Mani KR, Yajnik CS, Hofman A, Mattace-Raso FU, Oostra BA, Demirkan A, Isaacs A, Rivadeneira F, Lakatta EG, Orru M, Scuteri A, Ala-Korpela M, Kangas AJ, Lyytikainen LP, Soininen P, Tukiainen T, Wurtz P, Ong RT, Dorr M, Kroemer HK, Volker U, Volzke H, Galan P, Hercberg S, Lathrop M, Zelenika D, Deloukas P, Mangino M, Spector TD, Zhai G: Genetic variants in novel pathways influence blood pressure and cardiovascular disease risk. Nature 2011;478:103-109. 
18 Roos A, Boron WF: Intracellular pH. Physiol Rev 1981;61:296-434.

19 Boron WF: Regulation of intracellular $\mathrm{pH}$. Adv Physiol Educ 2004;28:160-179.

-20 Leem CH, Vaughan-Jones RD: Out-of-equilibrium $\mathrm{pH}$ transients in the guinea-pig ventricular myocyte. J Physiol 1998;509:471485.

-21 Swietach P, Camelliti P, Hulikova A, Kohl P, Vaughan-Jones RD: Spatial regulation of intracellular $\mathrm{pH}$ in multicellular strands of neonatal rat cardiomyocytes. Cardiovasc Res 2010;85:729-738.

22 Zaniboni M, Rossini A, Swietach P, Banger N, Spitzer KW, Vaughan-Jones RD: Proton permeation through the myocardial gap junction. Circ Res 2003;93:726-735.

-23 Swietach P, Rossini A, Spitzer KW, VaughanJones $\mathrm{RD}: \mathrm{H}^{+}$ion activation and inactivation of the ventricular gap junction: a basis for spatial regulation of intracellular $\mathrm{pH}$. Circ Res 2007;100:1045-1054.

-24 Fidelman ML, Seeholzer SH, Walsh KB, Moore RD: Intracellular $\mathrm{pH}$ mediates action of insulin on glycolysis in frog skeletal muscle. Am J Physiol 1982;242:C87-C93.

25 Aalkjaer C, Mulvany MJ: Steady-state effects of arginine vasopressin on force and $\mathrm{pH}_{\mathrm{i}}$ of isolated mesenteric resistance arteries from rats. Am J Physiol 1991;261:C1010-C1017.

-26 Naderali EK, Buttell N, Taggart MJ, Bullock AJ, Eisner DA, Wray S: The role of the sarcolemmal $\mathrm{Ca}^{2+}$-ATPase in the $\mathrm{pH}$ transients associated with contraction in rat smooth muscle. J Physiol 1997;505:329-336.

-27 Daugirdas JT, Arrieta J, Ye M, Flores G, Battle DC: Intracellular acidification associated with changes in free cytosolic calcium. Evidence for $\mathrm{Ca}^{2+} / \mathrm{H}^{+}$exchange via a plasma membrane $\mathrm{Ca}^{2+}$-ATPase in vascular smooth muscle cells. J Clin Invest 1995;95:14801489.

28 Boedtkjer E, Damkier HH, Aalkjaer C: NHE1 knockout reduces blood pressure and arterial media/lumen ratio with no effect on resting $\mathrm{pH}_{\mathrm{i}}$ in the vascular wall. J Physiol 2012;590:1895-1906.

-29 Boedtkjer E, Praetorius J, Aalkjaer C: NBCn1 (slc4a7) mediates the $\mathrm{Na}^{+}$-dependent bicarbonate transport important for regulation of intracellular $\mathrm{pH}$ in mouse vascular smooth muscle cells. Circ Res 2006;98:515-523.

-30 Aalkjaer C, Cragoe EJ Jr: Intracellular pH regulation in resting and contracting segments of rat mesenteric resistance vessels. J Physiol 1988;402:391-410.

-31 Aalkjaer C, Hughes A: Chloride and bicarbonate transport in rat resistance arteries. J Physiol 1991;436:57-73.

- 32 Aickin CC: Regulation of intracellular pH in smooth muscle cells of the guinea-pig femoral artery. J Physiol 1994;479:331-340.

-33 Choi I, Aalkjaer C, Boulpaep EL, Boron WF: An electroneutral sodium/bicarbonate cotransporter NBCn1 and associated sodium channel. Nature 2000;405:571-575.
34 Boedtkjer E, Praetorius J, Fuchtbauer EM, Aalkjaer C: Antibody-independent localization of the electroneutral $\mathrm{Na}^{+}-\mathrm{HCO}_{3}^{-} \mathrm{Co}-$ transporter $\mathrm{NBCn} 1$ (slc4a7) in mice. Am J Physiol Cell Physiol 2008;294:C591-C603.

35 Boedtkjer E, Bunch L, Pedersen SF: Physiology, pharmacology and pathophysiology of the $\mathrm{pH}$ regulatory transport proteins NHE1 and NBCn1: similarities, differences and implications for cancer therapy. Curr Pharm Des 2012;18:1345-1371.

-36 Bouzinova EV, Praetorius J, Virkki LV, Nielsen S, Boron WF, Aalkjaer C: $\mathrm{Na}^{+}$-dependent $\mathrm{HCO}_{3}^{-}$uptake into the rat choroid plexus epithelium is partially DIDS sensitive. Am J Physiol Cell Physiol 2005; 289:C1448-C1456.

-37 Praetorius J, Hager H, Nielsen S, Aalkjaer C, Friis UG, Ainsworth MA, Johansen T: Molecular and functional evidence for electrogenic and electroneutral $\mathrm{Na}^{+}-\mathrm{HCO}_{3}^{-}$cotransporters in murine duodenum. Am J Physiol Gastrointest Liver Physiol 2001;280:G332G343.

38 Odgaard E, Jakobsen JK, Frische S, Praetorius J, Nielsen $\mathrm{S}$, Aalkjaer $\mathrm{C}$, Leipziger J: Basolateral $\mathrm{Na}^{+}$-dependent $\mathrm{HCO}_{3}^{-}$transporter $\mathrm{NBCn} 1-$-mediated $\mathrm{HCO}_{3}^{-}$influx in rat medullary thick ascending limb. J Physiol 2004; 555:205-218.

39 Boron WF, Chen L, Parker MD: Modular structure of sodium-coupled bicarbonate transporters. J Exp Biol 2009;212:1697-1706.

-40 Boedtkjer E, Aalkjaer C: Insulin inhibits $\mathrm{Na}^{+} / \mathrm{H}^{+}$exchange in vascular smooth muscle and endothelial cells in situ: involvement of $\mathrm{H}_{2} \mathrm{O}_{2}$ and tyrosine phosphatase SHP-2. Am J Physiol Heart Circ Physiol 2009;296:H247H255.

41 Kalaria RN, Premkumar DR, Lin CW, Kroon SN, Bae JY, Sayre LM, LaManna JC: Identification and expression of the $\mathrm{Na}^{+} / \mathrm{H}^{+}$ exchanger in mammalian cerebrovascular and choroidal tissues: characterization by amiloride-sensitive $\left[{ }^{3} \mathrm{H}\right] \mathrm{MIA}$ binding and RT-PCR analysis. Brain Res Mol Brain Res 1998;58:178-187.

$42 \mathrm{Gu}$ XQ, Yao H, Haddad GG: Increased neuronal excitability and seizures in the $\mathrm{Na}^{+} / \mathrm{H}^{+}$ exchanger null mutant mouse. Am J Physiol Cell Physiol 2001;281:C496-C503.

43 Bell SM, Schreiner CM, Schultheis PJ, Miller ML, Evans RL, Vorhees CV, Shull GE, Scott WJ: Targeted disruption of the murine Nhel locus induces ataxia, growth retardation, and seizures. Am J Physiol 1999;276:C788C795.

44 Brosius FC III, Pisoni RL, Cao X, Deshmukh G, Yannoukakos D, Stuart-Tilley AK, Haller C, Alper SL: AE anion exchanger mRNA and protein expression in vascular smooth muscle cells, aorta, and renal microvessels. Am J Physiol 1997;273:F1039-F1047.
45 Davis JP, Chien PF, Chipperfield AR, Gordon A, Harper AA: The three mechanisms of intracellular chloride accumulation in vascular smooth muscle of human umbilical and placental arteries. Pflügers Arch 2000; 441:150-154.

46 Boedtkjer DM, Matchkov VV, Boedtkjer E, Nilsson H, Aalkjaer C: Vasomotion has chloride-dependency in rat mesenteric small arteries. Pflugers Arch 2008;457:389-404.

$\checkmark 47$ Floyd R, Wray S: Calcium transporters and signalling in smooth muscles. Cell Calcium 2007;42:467-476

-48 Yu K, Lujan R, Marmorstein A, Gabriel S, Hartzell HC: Bestrophin-2 mediates bicarbonate transport by goblet cells in mouse colon. J Clin Invest 2010;120:1722-1735.

49 Poulsen JH, Fischer H, Illek B, Machen TE: Bicarbonate conductance and $\mathrm{pH}$ regulatory capability of cystic fibrosis transmembrane conductance regulator. Proc Natl Acad Sci USA 1994;91:5340-5344.

50 Demaurex N: pH homeostasis of cellular organelles. News Physiol Sci 2002;17:1-5.

51 Damkier HH, Nielsen S, Praetorius J: An anti- $\mathrm{NH}_{2}$-terminal antibody localizes $\mathrm{NBCn} 1$ to heart endothelia and skeletal and vascular smooth muscle cells. Am J Physiol Heart Circ Physiol 2006;290:H172-H180.

52 Fenger-Gron J, Mulvany MJ, Christensen KL: Mesenteric blood pressure profile of conscious, freely moving rats. J Physiol 1995; 488:753-760.

53 Putnam RW, Grubbs RD: Steady-state $\mathrm{pH}_{\mathrm{i}}$, buffering power, and effect of $\mathrm{CO}_{2}$ in a smooth muscle-like cell line. Am J Physiol 1990;258:C461-C469.

54 Kahn AM, Cragoe EJ Jr, Allen JC, Seidel CL, Shelat $\mathrm{H}$ : Effects of $\mathrm{pH}_{\mathrm{i}}$ on $\mathrm{Na}^{+}-\mathrm{H}^{+}, \mathrm{Na}^{+}-$ dependent, and $\mathrm{Na}^{+}$-independent $\mathrm{Cl}^{-}-\mathrm{HCO}_{3}^{-}$ exchangers in vascular smooth muscle. Am J Physiol 1991;261:C837-C844.

55 Kahn AM, Cragoe EJ Jr, Allen JC, Halligan $\mathrm{RD}$, Shelat $\mathrm{H}: \mathrm{Na}^{+}-\mathrm{H}^{+}$and $\mathrm{Na}^{+}$-dependent $\mathrm{Cl}^{-}-\mathrm{HCO}_{3}^{-}$exchange control $\mathrm{pH}_{\mathrm{i}}$ in vascular smooth muscle. Am J Physiol 1990; 259:C134-C143.

-56 Sun B, Vaughan-Jones RD, Kambayashi JI: Two distinct $\mathrm{HCO}_{3}^{-}$-dependent $\mathrm{H}^{+}$efflux pathways in human vascular endothelial cells. Am J Physiol Heart Circ Physiol 1999; 277:H28-H32.

57 Taylor CJ, Nicola PA, Wang S, Barrand MA, Hladky SB: Transporters involved in regulation of intracellular $\mathrm{pH}$ in primary cultured rat brain endothelial cells. J Physiol 2006; 576:769-785.

58 Thyberg J: Differentiated properties and proliferation of arterial smooth muscle cells in culture. Int Rev Cytol 1996;169:183-265.

59 Thyberg J: Phenotypic modulation of smooth muscle cells during formation of neointimal thickenings following vascular injury. Histol Histopathol 1998;13:871-891. 
-60 Yu L, Quinn DA, Garg HG, Hales CA: Deficiency of the NHE1 gene prevents hypoxiainduced pulmonary hypertension and vascular remodeling. Am J Respir Crit Care Med 2008;177:1276-1284.

61 Yu L, Hales CA: Silencing of sodium-hydrogen exchanger 1 attenuates the proliferation, hypertrophy, and migration of pulmonary artery smooth muscle cells via E2F1. Am J Respir Cell Mol Biol 2011;45:923-930.

-62 Tian R, Vogel P, Lassen NA, Mulvany MJ, Andreasen F, Aalkjaer C: Role of extracellular and intracellular acidosis for hypercapniainduced inhibition of tension of isolated rat cerebral arteries. Circ Res 1995;76:269-275.

-63 Austin C, Wray S: Extracellular pH signals affect rat vascular tone by rapid transduction into intracellular $\mathrm{pH}$ changes. J Physiol 1993; 466:1-8.

64 Peng HL, Jensen PE, Nilsson H, Aalkjaer C: Effect of acidosis on tension and $\left[\mathrm{Ca}^{2+}\right]_{\mathrm{i}}$ in rat cerebral arteries: is there a role for membrane potential? Am J Physiol 1998; 274:H655-H662.

65 Rohra DK, Saito SY, Ohizumi Y: Low extracellular $\mathrm{Cl}^{-}$environment attenuates changes in intracellular $\mathrm{pH}$ and contraction following extracellular acidosis in Wistar Kyoto rat aorta. Pharmacology 2005;75:30-36.

-66 Smith GL, Austin C, Crichton C, Wray S: A review of the actions and control of intracellular $\mathrm{pH}$ in vascular smooth muscle. Cardiovasc Res 1998;38:316-331.

-67 McKinnon W, Aaronson PI, Knock G, Graves J, Poston L: Mechanism of lactate-induced relaxation of isolated rat mesenteric resistance arteries. J Physiol 1996;490:783-792.

68 Aaronson PI, McKinnon W, Poston L: Mechanism of butyrate-induced vasorelaxation of rat mesenteric resistance artery. Br J Pharmacol 1996;117:365-371.

-69 Aalkjaer C, Mortensen FV, Jensen PE, Nielsen $\mathrm{H}$ : The role of $\left[\mathrm{Ca}^{2+}\right]_{\mathrm{i}}$, membrane potential and $\mathrm{pH}_{\mathrm{i}}$ in the relaxation of rat mesenteric arteries to hyperosmolar acetate. Pflügers Arch 1998;436:705-711.

70 Musa-Aziz R, Chen LM, Pelletier MF, Boron WF: Relative $\mathrm{CO}_{2} / \mathrm{NH}_{3}$ selectivities of AQP1, AQP4, AQP5, AmtB, and RhAG. Proc Natl Acad Sci USA 2009;106:5406-5411.

71 Biver S, Belge H, Bourgeois S, Van VP, Nowik M, Scohy S, Houillier P, Szpirer J, Szpirer C, Wagner CA, Devuyst O, Marini AM: A role for Rhesus factor Rhcg in renal ammonium excretion and male fertility. Nature 2008; 456:339-343.

72 Kutchai H, Geddis LM: Lactate transport in rat aorta. Blood Vessels 1985;22:84-93.

73 Aronson PS, Suhm MA, Nee J: Interaction of external $\mathrm{H}^{+}$with the $\mathrm{Na}^{+}-\mathrm{H}^{+}$exchanger in renal microvillus membrane vesicles. J Biol Chem 1983;258:6767-6771.

74 Vaughan-Jones RD, Wu ML: Extracellular $\mathrm{H}^{+}$inactivation of $\mathrm{Na}^{+}-\mathrm{H}^{+}$exchange in the sheep cardiac Purkinje fibre. J Physiol 1990; 428:441-466.
75 Hulikova A, Vaughan-Jones RD, Swietach P: Dual role of $\mathrm{CO}_{2} / \mathrm{HCO}_{3}^{-}$buffer in the regulation of intracellular $\mathrm{pH}$ of three-dimensional tumor growths. J Biol Chem 2011;286: 13815-13826.

76 Aalkjaer C, Mulvany MJ: Effect of changes in intracellular $\mathrm{pH}$ on the contractility of rat resistance vessels. Prog Biochem Pharmacol 1988;23:150-158.

77 Matthews JG, Graves JE, Poston L: Relationships between $\mathrm{pH}_{\mathrm{i}}$ and tension in isolated rat mesenteric resistance arteries. J Vasc Res 1992;29:330-340.

78 Apkon M, Boron WF: Extracellular and intracellular alkalinization and the constriction of rat cerebral arterioles. J Physiol 1995; 484:743-753.

79 Nielsen H, Aalkjaer C, Mulvany MJ: Differential contractile effects of changes in carbon dioxide tension on rat mesenteric resistance arteries precontracted with noradrenaline. Pflügers Arch 1991;419:51-56.

80 Batlle DC, Peces R, LaPointe MS, Ye M, Daugirdas JT: Cytosolic free calcium regulation in response to acute changes in intracellular $\mathrm{pH}$ in vascular smooth muscle. Am J Physiol 1993;264:C932-C943.

-81 Jensen PE, Hughes A, Boonen HC, Aalkjaer C: Force, membrane potential, and $\left[\mathrm{Ca}^{2+}\right]_{\mathrm{i}}$ during activation of rat mesenteric small arteries with norepinephrine, potassium, aluminum fluoride, and phorbol ester. Effects of changes in $\mathrm{pH}_{\mathrm{i}}$. Circ Res 1993;73:314-324.

82 Raingo J, Rebolledo A, Grassi de Gende AO, Sanz N, Tommasi J, Milesi V: pH effects on high conductance $\mathrm{Ca}^{2+}$-activated $\mathrm{K}^{+}$channels $\left(\mathrm{BK}_{\mathrm{Ca}}\right)$ in human internal mammary artery smooth muscle cells. Life Sci 2005;77: 1993-2003.

83 Restini CA, Bendhack LM: Involvement of non-selective $\mathrm{Ca}^{2+}$ channels in the contraction induced by alkalinization of rat anococcygeus muscle cells. Eur J Pharmacol 2006; 553:288-296.

84 Kozak JA, Matsushita M, Nairn AC, Cahalan $\mathrm{MD}$ : Charge screening by internal $\mathrm{pH}$ and polyvalent cations as a mechanism for activation, inhibition, and rundown of TRPM7/ MIC channels. J Gen Physiol 2005;126:499514.

85 Park JK, Kim YC, Sim JH, Choi MY, Choi W, Hwang KK, Cho MC, Kim KW, Lim SW, Lee SJ: Regulation of membrane excitability by intracellular $\mathrm{pH}\left(\mathrm{pH}_{\mathrm{i}}\right)$ changers through $\mathrm{Ca}^{2+}$-activated $\mathrm{K}^{+}$current (BK channel) in single smooth muscle cells from rabbit basilar artery. Pflügers Arch 2007;454:307319.

86 Abercrombie RF, Hart CE: Calcium and proton buffering and diffusion in isolated cytoplasm from Myxicola axons. Am J Physiol 1986;250:C391-C405.

87 Gardner JP, Diecke FP: Influence of $\mathrm{pH}$ on isometric force development and relaxation in skinned vascular smooth muscle. Pflügers Arch 1988;412:231-239.
88 Mrwa U, Achtig I, Ruegg JC: Influences of calcium concentration and $\mathrm{pH}$ on the tension development and ATPase activity of the arterial actomyosin contractile system. Blood Vessels 1974;11:277-286.

89 Blumenthal DK, Stull JT: Effects of pH, ionic strength, and temperature on activation by calmodulin and catalytic activity of myosin light chain kinase. Biochemistry 1982;21: 2386-2391.

90 Arheden H, Arner A, Hellstrand P: Calcium sensitivity and energetics of contraction in skinned smooth muscle of the guinea pig taenia coli at altered pH. Pflügers Arch 1989; 413:476-481.

$>91$ Huang S, Cheung WY: $\mathrm{H}^{+}$is involved in the activation of calcineurin by calmodulin. J Biol Chem 1994;269:22067-22074.

92 Vanhoutte PM, Luscher TF, Graser T: Endothelium-dependent contractions. Blood Vessels 1991;28:74-83.

$>93$ Learmont JG, Cockell AP, Knock GA, Poston $\mathrm{L}$ : Myogenic and flow-mediated responses in isolated mesenteric small arteries from pregnant and nonpregnant rats. Am J Obstet Gynecol 1996;174:1631-1636.

94 Ganz MB, Boyarsky G, Sterzel RB, Boron WF: Arginine vasopressin enhances $\mathrm{pH}_{\mathrm{i}}$ regulation in the presence of $\mathrm{HCO}_{3}^{-}$by stimulating three acid-base transport systems. Nature 1989;337:648-651.

$\checkmark 95$ Bouyer P, Sakai H, Itokawa T, Kawano T, Fulton CM, Boron WF, Insogna KL: Colony-stimulating factor-1 increases osteoclast intracellular $\mathrm{pH}$ and promotes survival via the electroneutral $\mathrm{Na} / \mathrm{HCO}_{3}$ cotransporter NBCn1. Endocrinology 2007;148: 831-840.

$>96$ Denker SP, Huang DC, Orlowski J, Furthmayr H, Barber DL: Direct binding of the $\mathrm{Na}-\mathrm{H}$ exchanger NHE1 to ERM proteins regulates the cortical cytoskeleton and cell shape independently of $\mathrm{H}^{+}$translocation. Mol Cell 2000;6:1425-1436.

$\checkmark 97$ Denker SP, Barber DL: Cell migration requires both ion translocation and cytoskeletal anchoring by the $\mathrm{Na}-\mathrm{H}$ exchanger NHE1. J Cell Biol 2002;159:1087-1096.

-98 Hunter DJ, Altshuler D, Rader DJ: From Darwin's finches to canaries in the coal mine mining the genome for new biology. N Engl J Med 2008;358:2760-2763.

99 Kathiresan S, Melander O, Guiducci C, Surti A, Burtt NP, Rieder MJ, Cooper GM, Roos C, Voight BF, Havulinna AS, Wahlstrand B, Hedner T, Corella D, Tai ES, Ordovas JM, Berglund G, Vartiainen E, Jousilahti P, Hedblad B, Taskinen MR, Newton-Cheh C, Salomaa V, Peltonen L, Groop L, Altshuler DM, Orho-Melander M: Six new loci associated with blood low-density lipoprotein cholesterol, high-density lipoprotein cholesterol or triglycerides in humans. Nat Genet 2008;40:189-197. 
100 Molgaard J, von SH, Olsson AG: Effects of simvastatin on plasma lipid, lipoprotein and apolipoprotein concentrations in hypercholesterolaemia. Eur Heart J 1988;9: 541-551.

101 Siffert W, Dusing R: Sodium-proton exchange and primary hypertension. An update. Hypertension 1995;26:649-655.

102 Rosskopf D, Fromter E, Siffert W: Hypertensive sodium-proton exchanger phenotype persists in immortalized lymphoblasts from essential hypertensive patients. A cell culture model for human hypertension. J Clin Invest 1993;92:2553-2559.

-103 Dudley CR, Giuffra LA, Raine AE, Reeders ST: Assessing the role of APNH, a gene encoding for a human amiloride-sensitive $\mathrm{Na}^{+} / \mathrm{H}^{+}$antiporter, on the interindividual variation in red cell $\mathrm{Na}^{+} / \mathrm{Li}^{+}$countertransport. J Am Soc Nephrol 1991;2:937-943.

-104 Lifton RP, Hunt SC, Williams RR, Pouyssegur J, Lalouel JM: Exclusion of the $\mathrm{Na}^{+}$$\mathrm{H}^{+}$antiporter as a candidate gene in human essential hypertension. Hypertension 1991; 17:8-14.

105 Izzard AS, Heagerty AM: The measurement of internal $\mathrm{pH}$ in resistance arterioles: evidence that intracellular $\mathrm{pH}$ is more alkaline in SHR than WKY animals. J Hypertens 1989;7:173-180.

-106 Scuteri A, Jensen PE, Aalkjaer C: The regulation of $\mathrm{pH}$ in resistance arteries from spontaneously hypertensive and WistarKyoto rats: the effect of bicarbonate. J Hypertens 1995;13:523-528.

107 Orlov SN, Adarichev VA, Devlin AM, Maximova NV, Sun YL, Tremblay J, Dominiczak AF, Postnov YV, Hamet P: Increased $\mathrm{Na}^{+} / \mathrm{H}^{+}$exchanger isoform 1 activity in spontaneously hypertensive rats: lack of mutations within the coding region of NHE1. Biochim Biophys Acta 2000;1500: 169-180.

- 108 LaPointe MS, Ye M, Moe OW, Alpern RJ, Batlle DC: $\mathrm{Na}^{+} / \mathrm{H}^{+}$antiporter (NHE-1 isoform) in cultured vascular smooth muscle from the spontaneously hypertensive rat. Kidney Int 1995;47:78-87.

109 Lucchesi PA, DeRoux N, Berk BC: $\mathrm{Na}^{+}-\mathrm{H}^{+}$ exchanger expression in vascular smooth muscle of spontaneously hypertensive and Wistar-Kyoto rats. Hypertension 1994;24: 734-738.

110 Siczkowski M, Ng LL: Phorbol ester activation of the rat vascular myocyte $\mathrm{Na}^{+}-\mathrm{H}^{+}$exchanger isoform 1. Hypertension 1996;27: 859-866.
111 Siczkowski M, Davies JE, Ng LL: Sodiumhydrogen antiporter protein in normotensive Wistar-Kyoto rats and spontaneously hypertensive rats. J Hypertens 1994;12: 775-781.

112 Siczkowski M, Davies JE, Ng LL: $\mathrm{Na}^{+}-\mathrm{H}^{+}$exchanger isoform 1 phosphorylation in normal Wistar-Kyoto and spontaneously hypertensive rats. Circ Res 1995;76:825-831.

113 LaPointe MS, Ye M, Bacallao R, Batlle D: NHE-1 protein in vascular smooth muscle and lymphocytes from the spontaneously hypertensive rat. Hypertension 1997;30: 880-885.

114 Kuro-o M, Hanaoka K, Hiroi Y, Noguchi T, Fujimori Y, Takewaki S, Hayasaka M, Katoh H, Miyagishi A, Nagai R, Yazaki Y, Nabeshima Y: Salt-sensitive hypertension in transgenic mice overexpressing $\mathrm{Na}^{+}$-proton exchanger. Circ Res 1995;76:148-153.

115 Gumina RJ, Buerger E, Eickmeier C, Moore J, Daemmgen J, Gross GJ: Inhibition of the $\mathrm{Na}^{+} / \mathrm{H}^{+}$exchanger confers greater cardioprotection against 90 minutes of myocardial ischemia than ischemic preconditioning in dogs. Circulation 1999;100:25192526.

116 Hendrikx M, Mubagwa K, Verdonck F, Overloop K, Van HP, Vanstapel F, Van LA, Verbeken E, Lauweryns J, Flameng W: New $\mathrm{Na}^{+}-\mathrm{H}^{+}$exchange inhibitor HOE 694 improves postischemic function and high-energy phosphate resynthesis and reduces $\mathrm{Ca}^{2+}$ overload in isolated perfused rabbit heart. Circulation 1994;89:2787-2798.

117 Maddaford TG, Pierce GN: Myocardial dysfunction is associated with activation of $\mathrm{Na}^{+} / \mathrm{H}^{+}$exchange immediately during reperfusion. Am J Physiol 1997;273:H2232H2239.

118 Dong YY, Wu M, Yim AP, He GW: Effect of hypoxia-reoxygenation on endothelial function in porcine cardiac microveins. Ann Thorac Surg 2006;81:1708-1714.

119 Dong YY, Wu M, Yim AP, He GW: Hypoxia-reoxygenation, St. Thomas cardioplegic solution, and nicorandil on endotheliumderived hyperpolarizing factor in coronary microarteries. Ann Thorac Surg 2005;80: 1803-1811.

120 Besse S, Tanguy S, Boucher F, Huraux C, Riou B, Swynghedauw B, de Leiris J: Protection of endothelial-derived vasorelaxation with cariporide, a sodium-proton exchanger inhibitor, after prolonged hypoxia and hypoxia-reoxygenation: effect of age. Eur Pharmacol 2006;531:187-193.
121 Hattori R, Otani H, Moriguchi Y, Matsubara $H$, Yamamura T, Nakao Y, Omiya $H$, Osako M, Imamura H: NHE and ICAM-1 expression in hypoxic/reoxygenated coronary microvascular endothelial cells. Am J Physiol Heart Circ Physiol 2001;280: H2796-H2803.

122 Liu H, Cala PM, Anderson SE: Na/H exchange inhibition protects newborn heart from ischemia/reperfusion injury by limiting $\mathrm{Na}^{+}$-dependent $\mathrm{Ca}^{2+}$ overload. J Cardiovasc Pharmacol 2010;55:227-233.

123 Schafer C, Ladilov YV, Schafer M, Piper HM: Inhibition of NHE protects reoxygenated cardiomyocytes independently of anoxic $\mathrm{Ca}^{2+}$ overload and acidosis. Am J Physiol Heart Circ Physiol 2000;279: H2143-H2150.

124 Li C, Jackson RM: Reactive species mechanisms of cellular hypoxia-reoxygenation injury. Am J Physiol Cell Physiol 2002; 282:C227-C241.

125 Colantuoni A, Lapi D, Paterni M, Marchiafava PL: Protective effects of insulin during ischemia-reperfusion injury in hamster cheek pouch microcirculation. J Vasc Res 2005;42:55-66.

126 Kahn AM, Yang M: Insulin increases acid production and may directly stimulate $\mathrm{Na}^{+} / \mathrm{H}^{+}$exchange activity in cultured vascular smooth muscle cells. J Vasc Res 2011; 48:505-512.

127 Mentzer RM Jr, Bartels C, Bolli R, Boyce S, Buckberg GD, Chaitman B, Haverich A, Knight J, Menasche P, Myers ML, Nicolau J, Simoons M, Thulin L, Weisel RD, EXPEDITION Study Investigators: Sodium-hydrogen exchange inhibition by cariporide to reduce the risk of ischemic cardiac events in patients undergoing coronary artery bypass grafting: results of the EXPEDITION study. Ann Thorac Surg 2008;85:1261-1270.

-128 Zeymer U, Suryapranata H, Monassier JP, Opolski G, Davies J, Rasmanis G, Linssen G, Tebbe U, Schroder R, Tiemann R, Machnig T, Neuhaus KL: The $\mathrm{Na}^{+} / \mathrm{H}^{+}$exchange inhibitor eniporide as an adjunct to early reperfusion therapy for acute myocardial infarction. Results of the evaluation of the safety and cardioprotective effects of eniporide in acute myocardial infarction (ESCAMI) trial. J Am Coll Cardiol 2001;38: 1644-1650.

129 Schafer C, Ladilov YV, Siegmund B, Piper HM: Importance of bicarbonate transport for protection of cardiomyocytes against reoxygenation injury. Am J Physiol Heart Circ Physiol 2000;278:H1457-H1463. 